IZA DP No. 1209

Poverty Persistence in Sweden

J orgen Hansen

Roger Wahl berg

J uly 2004 


\title{
Poverty Persistence in Sweden
}

\author{
Jorgen Hansen \\ Concordia University, CEPR, \\ CIREQ, CIRANO and IZA Bonn \\ Roger Wahlberg \\ University of Gothenburg
Discussion Paper No. 1209 July 2004

\author{
IZA \\ P.O. Box 7240 \\ 53072 Bonn \\ Germany \\ Phone: +49-228-3894-0 \\ Fax: +49-228-3894-180 \\ Email: iza@iza.org
}

\begin{abstract}
Any opinions expressed here are those of the author(s) and not those of the institute. Research disseminated by IZA may include views on policy, but the institute itself takes no institutional policy positions.
\end{abstract}

The Institute for the Study of Labor (IZA) in Bonn is a local and virtual international research center and a place of communication between science, politics and business. IZA is an independent nonprofit company supported by Deutsche Post World Net. The center is associated with the University of Bonn and offers a stimulating research environment through its research networks, research support, and visitors and doctoral programs. IZA engages in (i) original and internationally competitive research in all fields of labor economics, (ii) development of policy concepts, and (iii) dissemination of research results and concepts to the interested public.

IZA Discussion Papers often represent preliminary work and are circulated to encourage discussion. Citation of such a paper should account for its provisional character. A revised version may be available on the IZA website (www.iza.org) or directly from the author. 


\section{ABSTRACT}

\section{Poverty Persistence in Sweden*}

This paper analyzes the persistence of poverty in Sweden using a hazard rate model based on multiple spells. The model also accounts for unobserved heterogeneity and possibly endogenous initial conditions. We estimate the model on a large representative Swedish panel data set, LINDA, for the years 1991 to 2001. The data contains precise information on household disposable income obtained from individual tax files. Poverty is defined using information on annual minimum needs standards determined by the Swedish National Board of Health and Welfare. The data indicates that poverty rates are highest for immigrants, especially refugee immigrants, and for households with children. Further, poverty rates declined, both for natives and for immigrants, between 1991 and 2001, partly as a result of improved labor market conditions. The empirical results suggest that there is significant negative duration dependence in both exit and entry hazard rates. Moreover, the transition rates are significantly affected by immigrant status, educational attainment, labor market conditions, age, and family status. Accounting for multiple spells shows that for two-parent families with two children who are represented by a male person, 44 percent of native households that falls into poverty at any given point in time remain poor in five or more out of the next ten years. For refugee and non-refugee households, the figures are 62 percent and 50 percent, respectively.

JEL Classification: $\quad$ C23, C41, D31, I32, J15, J61

Keywords: poverty persistence, duration dependence, multiple spells, unobserved heterogeneity

Corresponding author:

Jorgen Hansen

Department of Economics

Concordia University

1455, de Maisonneuve Blvd W.

Montreal, Quebec, H3G 1M8

Canada

Email: hansen@alcor.concordia.ca

\footnotetext{
* Financial support from the Jan Wallander and Tom Hedelius Foundation for Research in Economics is gratefully acknowledged.
} 


\section{Introduction}

Much of the debate on poverty, both past and current, has focused on the possibility that poverty is a condition that affects relatively few households, but those affected remains in poverty for a sizeable portion of their lifetimes (e.g. Bane and Elwood (1986), Stevens (1994 and 1999), Oxley et al. (2000), Devicienti (2001), Cappellari and Jenkins (2002), Biewen (2003), and Finnie and Sweetman (2003)). While it is well recognized that poverty rates are helpful indicators of the level of poverty in any given year, these rates ignore important underlying dynamics in poverty. An understanding of the dynamic aspects of poverty is essential from a policy perspective since different policies are more likely to be effective depending on the nature of poverty. From cross-sectional poverty rates, it is not possible to say if a particular poverty level is mainly due to a high risk of becoming poor (inflow rate) combined with a relatively high possibility of leaving poverty (outflow rate), or if the poverty level instead is due to a low risk of becoming poor combined with a low chance of leaving poverty. In the former case, poverty is a relatively brief condition while it is more persistent in the latter case. Gaining insight about the flows into and out-of poverty allows a better description of the poor in any given year and also identifies groups that need to be targeted by poverty reducing policies. If poverty dynamics are described by a high incidence of becoming poor in conjunction with high exit probabilities, short-term income support programs are appropriate. On the other hand, if poverty is a condition experienced only by a small subpopulation but with high persistence, there is a stronger need for active programs designed to improve long-term labor market outcomes for this group.

Poverty can broadly be defined as a condition that occurs when a household's net (or disposable) income falls below a minimum needs standard. The resources of households in poverty are then insufficient to meet the basic needs of the family. In this paper, we define households as poor in any given year, if total disposable family income - adjusted for household size - falls below the minimum needs standard in that year. In Sweden, The National Board of Health and Welfare (Socialstyrelsen) provide information about the minimum needs standard (Socialbidragsnormen) which is designed to cover basic expenditures on food, clothing, electricity, insurances, and health. In the literature on 
poverty and poverty dynamics, it is common to define a household as poor when net household income falls below 50 percent of the median (or sometimes the mean) net household income (see for instance Oxley et al. (2000), Devicienti (2001), Biewen (2003), Finnie and Sweetman (2003)). With this definition, actual income levels are irrelevant and only relative income levels matter. For instance, if household net income is reduced for every household, but more so for household with higher income levels, poverty is reduced despite the fact that all households have less income than before. One advantage of using the minimum needs standard to define poverty instead of relying on the distribution of income is the fact that it reflects what the government sees as the minimum level of income that families need for their subsistence.

While the Swedish welfare system is well recognized in an international perspective because of a high degree of income security and relatively low poverty rates, there is still a concern about “poverty traps” and exclusions from the labor market among certain groups. This concern is highlighted in recent reports published by the Ministry of Finance and the National Board of Health and Welfare, which provide descriptions of poverty rates since 1991, as well as discussions about the transition rates into and out-of poverty (see National Board of Health and Welfare (2001) and Ministry of Finance (2003)). ${ }^{1}$ During the first half of the 1990s, Sweden experienced an unprecedented increase in unemployment. Over the same time period, there were also substantial reductions in many government transfers and a large number of refugee immigrants arrived. Despite these events, poverty rates according to our definition remained fairly constant. Since the mid-1990s, poverty rates have decreased along with improvements in the labor market and reductions in the unemployment rates.

In this paper, we document the development of poverty in Sweden between 1991 and 2001, and also identify different groups who appear more likely to be affected by poverty, with particular focus on native-immigrant differences. We will also address the issue of "poverty trap” and assess the effect of past poverty experiences on current poverty probabilities. Finally, given the dramatic changes in the labor market during the

\footnotetext{
${ }^{1}$ See also Halleröd (1999) for a thorough description of poverty in Sweden.
} 
1990s in Sweden, we will also estimate the impact of local labor market conditions on the probabilities of leaving and entering poverty.

When studying poverty persistence, it is important to recognize the possibility that households that have left poverty may soon fall back into poverty. This perspective has been pointed out by Stevens (1999) and implies that focusing only on single poverty spells, as opposed to multiple spells, may significantly underestimate the total time spent below the poverty line. While long single poverty spells obviously imply that a substantial fraction of time is spent in poverty, repeated poverty spells with intermittent periods of non-poverty also lead to significant periods in poverty. It is also necessary to allow for correlation between exit and reentry probabilities to accurately estimate total spent in poverty. For example, a household that has experienced a long poverty spell and then reenters poverty may be more likely to experience another long poverty spell. Moreover, it may be the case that households with particularly high exit rates also have low reentry rates. In both these cases, assuming independence between the transition rates will bias the results, and the empirical model that is used should attempt to control for this matter.

While most studies on poverty persistence (e.g. Lilliard and Willis (1978), Bane and Ellwood (1986), Stevens (1994), Oxley et al. (2000), and Finnie and Sweetman (2003)) have ignored the use of multiple spells and/or correlations between transition probabilities, recent work by Stevens (1999), Devicienti (2001), Cappellari and Jenkins (2002), and Biewen (2003) have explicitly allowed for these issues. The analysis presented in this paper builds on the work presented in these recent papers. The main differences between this study and the preceding ones are the nature of the data that is used and the definition of poverty. While virtually all of the previous work have used survey data (one exception being Finnie and Sweetman (2003)), we are using data extracted from administrative records which imply essentially no attrition and accurate income measures. The data, which is a representative longitudinal data set, Longitudinal Individual Data (LINDA), contains information on more than 300,000 individuals annually for the period 1991 to 2001. Disposable income for a given household, which is 
used to derive poverty status, is obtained by adding all sources of income net of taxes, including government transfers. More details on the definition of poverty status are provided in the data section below.

The empirical results suggest existence of substantial poverty persistence. We divided our sample into six categories depending on the gender and immigrant status of the person representing the household, and we find evidence of significant, negative duration dependence for all these groups. The use of multiple poverty spells clearly show that total time in poverty can be seriously underestimated in single-spell models. For male singleadult households with no children, we find that natives spend 3-4 years in poverty out of the next ten conditioning on being poor initially, depending on educational attainment. Similar results were obtained for refugee and non-refugee immigrants. Among male represented households with children, regardless of marital status, expected years in poverty are higher for both natives (4-5 years) and immigrants (5-6 years). For female single-adult households with no children, natives spend between 2-3 years in poverty out of the next ten, again conditioning on being poor initially and depending on educational attainment. The figures for immigrant women are higher, 3-5 years for refugee women and 3-4 years for non-refugee women. Looking at female represented households with children, natives spend about 6 years in poverty out of the next ten, refugees spend 6-7 years in poverty and non-refugees spend about 5 years in poverty. Thus, the family types that appear to be "trapped” in poverty are households with children, regardless of whether it is a single-parent or a two-parent household. Further, among these households, immigrant families spend more time in poverty than similar native families.

The remainder of the paper is organized as follows. Section 2 provides a description of the data and the definition of poverty status. The empirical model is presented in Section 3, while the results are shown in Section 4. A summary is provided in Section 5. 


\section{Data}

\subsection{Description of the Data and Sampling Procedures}

The data used in this paper is taken from a recently created Swedish longitudinal data set, Longitudinal Individual Data (LINDA). LINDA is a register-based data set and it consists of a large panel of individuals, and their household members, which are representative for the population from 1960 to 2001. LINDA is a joint endeavor between the Department of Economics at Uppsala University, The National Social Insurance Board (RFV), Statistics Sweden, and the Ministries of Finance and Labor. The main administrator of the data set is Statistics Sweden. For a more detailed description of the data used here, including the sampling structure, see Edin and Fredriksson (2000).

LINDA contains a 3 percent representative random sample of the Swedish population, corresponding to approximately 300,000 individuals for the period studied here. The sampled population consists of all individuals, including children and elderly persons, who lived in Sweden during a particular year. The sampling procedure used in constructing the panel data set ensures that each cross-section is representative for the population in each year. The sample used in this study consists of information from LINDA for the years 1991-2001. ${ }^{2}$ We excluded all individuals younger than 18 years or older than 65 years, students, self-employed, and retired individuals. Further, we excluded individuals who did not participate in all 11 waves. A person is defined to be an immigrant if he/she was born abroad, and refugee immigrant if he/she was born in a refugee country, as defined by the Swedish Immigration Board, or in a sub-Saharan country. ${ }^{3}$

\footnotetext{
${ }^{2}$ We lack information on certain variables prior to 1991.

${ }^{3}$ LINDA does not provide any information regarding refugee status. However, by using the countries defined by the Swedish Immigration Board as refugee countries (which vary over time) along with information on country of birth as well as time of arrival in Sweden, we can obtain an approximate measure of refugee status. It should be noted that all immigrant households included in LINDA, whether defined as refugees or not, have obtained residence permits. This means, for instance, that asylum seekers who have not yet obtained a residence permit are not included in LINDA. Furthermore, the data does not allow us to identify the exact year of arrival for immigrants who arrived in 1968 or earlier.
} 


\subsection{Variable Definitions}

As mentioned above, there exists no well-defined measure of poverty status in the literature. Generally, in the economics literature, individuals or households are defined as poor in a given time period if their total family income net of taxes and transfers is below one half of the median or mean of adjusted household income. An alternative way to define poverty is to compare net household income to a pre-determined needs standard (e.g. Bane and Elwood (1986), Stevens (1994 and 1999)). However, regardless of poverty definition, the information on household net income is crucial. Most existing studies rely on information drawn from survey data where there are potentially large measurement errors in reported income sources. The rich and precise information on incomes and transfers obtained from tax registers in LINDA allow us to obtain an accurate measure of household disposable income. We let the sampled individual represent the household and consider a household as poor in any given year if the adjusted family disposable income is below the minimum needs standard set by The National Board of Health and Welfare (Socialstyrelsen). We have only been able to obtain these minimum needs standards for the years 1996-97, and 1999-2001. Therefore, we use the 1996 standard for the years prior to 1996, and the 1999 standard for 1998. All income levels are expressed in 2001

prices. The adjusted income measure is used in order to compare the economic standard between households of different size and composition, and the adjustment factor is defined as:

$$
\text { (Number of adults }+0.7 * \text { Number of Children) }{ }^{0.7}
$$

which is the equivalence scale used by the Swedish Ministry of Finance (Ministry of Finance (2003)).

LINDA also provides information on standard observable characteristics, such as age, education, marital status, number and age of children, and region of residence, and all these variables enter our empirical model as observable covariates. We are also able to identify couples who live together but are not legally married, as long as they have children below 18 years of age. To account for variation in economic conditions, we add 
information from Statistics Sweden's labor force surveys on unemployment rates. The unemployment rates are tabulated for each municipality (there are around 280 municipalities in Sweden), gender and age group. Thus, we have a large cross-sectional variation, in addition to variation over time, in our measure of labor market tightness.

\subsection{Description of Poverty and Poverty Dynamics}

Tables 1 and 2 present descriptive statistics for a balanced sample of men and women, by immigrant category (native born, refugee immigrants and non-refugee immigrants). The entries in the tables indicate that refugee immigrants have more children than the other two groups, and they are also more concentrated in urban areas. The average poverty rates over the period 1991-2001 differ substantially across the three categories: 0.08 for natives (both men and women), 0.25 for male refugees, 0.20 for female refugees, 0.14 for male non-refugees, and 0.10 for female non-refugees.

In Figures 1 and 2, we present annual poverty rates for the time period covered in this paper, 1991-2001, by gender and immigrant category. As was shown above, the rates are highest for refugee immigrants, and lowest for native born persons. Between 1991 and 1996, the poverty rates increased slightly for all groups. The largest increase, in absolute terms, is observed for refugees and the smallest for natives. However, between 1997 and 2001, the poverty rates decreased substantially. For native men, the poverty rates decreased from 10.1 percent to 3.9 percent, while for male refugee immigrants, the rates decreased from 29.3 percent to 15.4 percent. For male non-refugee immigrants, the poverty rates decreased from 15.8 percent to 8.4 percent. The pattern is similar for women, and indicates that the improvements in the labor market, with substantial reductions in the unemployment rate (from 8.6 percent in 1997 to 4.4 percent in 2001), is strongly correlated with poverty reductions. However, despite large reductions in poverty in absolute terms, poverty rates for immigrants are still substantially higher than those for native born persons.

Changes in cross-sectional poverty rates may be due to changes in inflow rates and/or changes in outflow rates. In Figures 3-6, we present transition probabilities (the inflow 
and the outflow rates) by year, gender and immigrant category. The pattern in Figure 3 and Figure 4 shows that the inflow rate decreased between 1991 and 2001 for all groups. During the same period, the outflow or exit rates (shown in Figures 5 and 6) increased for natives and non-refugee immigrants. For refugee immigrants, the increase in outflow rates was smaller, and for refugee women, the outflow rate was relatively constant between 1991 and 2001. Thus, it appears as if the reduction in poverty rates for refugees was mainly driven by reductions in inflow rates, while for natives and non-refugees, poverty reductions are due both to reduced inflow rates and increased outflow rates.

To illustrate the importance of using a multiple spell framework as opposed to a single spell model, Tables 3 and 4 shows the total number of years in poverty during the period 1991-2001 for men and women, respectively. The entries are conditional on having experienced some poverty during this period. For men, the single spell measure indicates that 34 percent of native men experienced only one year in poverty (28 percent for refugee immigrants and 33 percent for non-refugee immigrants) and the average number of years equals 3.7 years ( 4.5 years for refugees and 4.1 years for non-refugees). When we consider multiple spells, we find that only 23 percent of native men experienced only one year in poverty (16.5 percent for refugee men and 21 percent for non-refugee men) and the average number of years equals 4.3 years ( 5.4 years for refugees and 4.9 years for non-refugees). Thus, it is quite clear that focusing on single spells only substantially underestimates the total years in poverty. Table 4 shows the entries for women, and overall we observe the same pattern as for men. The entries in both tables also show a large difference in total years in poverty across immigrant groups. Among refugee immigrants, 10-12 percent is defined as poor in all 11 years, while the corresponding numbers for natives are 4-5 percent. This further illustrates the lower exit rates among refugee immigrants compared to natives, and indicate that poverty is a relatively persistent phenomenon among refugee immigrants and less so among native-born Swedes.

Table 5 shows the distribution of years in poverty over the period 1991-2001, including those who did not experience any poverty during this period. About 22 percent of native 
men experienced some poverty during this period, while over 51 percent of refugee men had at least one year with net household income below the minimum needs standard. For non-refugee men, the number is 31 percent. Less than 1 percent of native men were poor in all 11 years. For refugee men, this number is just over 5 percent while 2.9 percent of non-refugee men were poor in all 11 years. Across all immigrant groups, men and women appear to have quite similar distributions in years in poverty.

\section{Empirical Specification}

In this section, we present a multiple spell hazard model which will allow us to asses the importance of duration dependence in poverty as well as the impact of observable characteristics, such as education and labor market conditions, on poverty exits and entries. Since it is likely that unobservable characteristics, such as labor market ability, motivation, preferences for leisure etc., will play a role in determining the transitions into and out-of poverty, it is important to formulate a model that attempts to control for these matters. The empirical model presented in this section is similar to that presented by Meghir and Whitehouse (1997), and within a poverty context, it has been used by Stevens (1999), Devicienti (2001), and Biewen (2003), among others. The hazard rate for household $h$ for leaving poverty at time $t$ is specified as:

$$
\lambda_{h t}^{E P}\left(d_{h, t-1} \mid \mu_{h}^{E P}\right)=\Phi\left(\mu_{h}^{E P}+\mathbf{X}_{h, t-1} \beta^{E P}+\gamma^{E P}\left(d_{h, t-1}\right)\right)
$$

where $\mu_{h}^{E P}$ is an unobserved, time-invariant, household-specific effect (representing ability, motivation, preferences, etc.), $\mathbf{X}_{h, t-1}$ is a vector containing observable characteristics, $\gamma^{E P}\left(d_{h, t-1}\right)$ is a flexibly specified function designed to capture duration dependence, and $\Phi($.$) the standard normal cdf. The hazard rate for household h$ for leaving non-poverty at time $t$ is similarly defined:

$$
\lambda_{h t}^{E N P}\left(d_{h, t-1} \mid \mu_{h}^{N P}\right)=\Phi\left(\mu_{h}^{N P}+\mathbf{X}_{h, t-1} \beta^{N P}+\gamma^{N P}\left(d_{h, t-1}\right)\right)
$$


Because the hazard rates explicitly depend on poverty and non-poverty durations, we need to condition on the state in which a person is initially observed. However, the initial state is likely to be endogenous, meaning that selection into poverty and non-poverty in the initial period is not random but instead depends on both observed and unobserved household characteristics. To address this issue, we adopt a procedure similar to that suggested by Heckman (1981). For the initial period the individual is observed ( $t=1)$, we estimate the following static Probit model:

$$
P_{h 1}^{I N}\left(\mu_{h}^{I N}\right)=\Phi\left(\mu_{h}^{I N}+\mathbf{X}_{h, 1} \beta^{I N}\right)
$$

where $\mu_{h}^{I N}$ is an unobserved, time-invariant, household-specific effect determining the probability of being poor at time $t=1, \mathbf{X}_{h, 1}$ is a vector containing observable characteristics as of time $t=1$, and $P_{h 1}^{I N}\left(\mu_{h}^{I N}\right)$ is the probability of being poor in the initial period, conditional on $\mu_{h}^{I N}$. This procedure approximates the initial conditions for the model, and Heckman (1981) reports that this approximation, in a binary choice model, performs well and that the procedure leads to only a small asymptotic bias.

The likelihood contribution for household $h$, conditional on observed and unobserved characteristics, can then be written as:

$$
\begin{aligned}
L_{h}\left(\mu_{h}\right)= & {\left[P_{h 1}\left(\mu_{h}^{I N}\right)^{p_{h 1}}\left(1-P_{h 1}\left(\mu_{h}^{I N}\right)^{\left(1-p_{h 1}\right)}\right)\right] \times } \\
& \prod_{t=2}^{T}\left\{\begin{array}{l}
{\left[\left(1-\lambda_{h t}^{E P}\left(d_{h, t-1} \mid \mu_{h}^{E P}\right)\right)^{\left(1-e_{h t}\right)} \lambda_{h t}^{E P}\left(d_{h, t-1} \mid \mu_{h}^{E P}\right)^{e_{h t}}\right]^{p_{h, t-1}} \times} \\
{\left[\left(1-\lambda_{h t}^{E N P}\left(d_{h, t-1} \mid \mu_{h}^{E N P}\right)\right)^{\left(1-e_{h t}\right)} \lambda_{h t}^{E N P}\left(d_{h, t-1} \mid \mu_{h}^{E N P}\right)^{e_{h t}}\right]^{\left(1-p_{h, t-1}\right)}}
\end{array}\right\}
\end{aligned}
$$

where $\mu_{h}=\left\{\mu_{h}^{I N}, \mu_{h}^{E P}, \mu_{h}^{E N P}\right\}$. In order to empirically implement the model, we need to specify the stochastic nature of unobserved heterogeneity. We choose to formulate a finite mixture model, which allows for unobserved heterogeneity in a flexible way without imposing a parametric structure, following Heckman and Singer (1984). We 
assume that there exist $M$ different sets of $\mu_{h},\left\{\mu_{h}(1), \mu_{h}(2), \ldots, \mu_{h}(M)\right\}$ that determine a family's preferences/ability, each observed with probability $\pi_{\mathrm{m}}$ (where $\pi_{\mathrm{m}}>0$ and $\Sigma \pi_{\mathrm{m}}$ $=1, m=1, \ldots, M)$. This specification allows for arbitrary correlations between poverty entry and exit rates as well as between the transition rates and the initial conditions.

Given the distributional assumptions of the unobserved heterogeneity components, the contribution to the likelihood function for a given household, $h$, is

$$
\log L_{h}=\log \sum_{m=1}^{M} \pi_{m} L_{h}\left(\mu_{h}(m)\right)
$$

We experimented with different values for $M$, and found that a model with $M=2$ fitted the data quite well. This low dimensionality has been found in many studies of mixture models (e.g. Hansen and Lofstrom (2001), Cameron and Heckman (2001), Stevens (1999), Ham and Lalonde (1996), and Eberwein, Ham and Lalonde (1997)).

\section{Results}

We report results from maximizing the likelihood function above in Tables 6 and 7, for men and women respectively. The estimates show that the observable characteristics have predictable effects on the probabilities of leaving and entering poverty. For native men, being single and low-educated is associated with a lower likelihood of leaving poverty. The local unemployment rate and number of children in the household also have negative and significant effects on the probability of exiting poverty. The coefficients on age and region of residence reveal that the exit probability increase with age and is lower in rural areas. The effects of these covariates on the entry rates are also as expected. Higher educational attainment reduces the risk of becoming poor, while more children increases that risk. The entry rate is also lower for older individuals and higher in rural areas. Finally, the labor market is a strong determinant of poverty entries as indicated by the positive and significant estimate on the local unemployment rate. There is also evidence on negative duration dependence in both the exit and the entry probabilities. For 
male immigrants, there is a similar pattern in the estimated coefficients. However, the effect of high-school education is not significant. Further, area of residence is not a significant determinant of the probability of leaving or entering poverty. The effect of duration on the exit and entry rate is negative and significant, both for refugee immigrants and non-refugee immigrants. Finally, there is no indication that the exit and entry rates significantly depend on time spent in Sweden, as the coefficients on years since migration and on the arrival cohort dummies are generally not significant. The estimates for women, shown in Table 7, are similar to those for males. Marital status, education, number of children, age and local unemployment rate significantly affect the hazard rates in expected ways. The effects of these observable characteristics will be further illustrated below using simulated distributions of time spent in poverty.

The estimated distribution of unobserved heterogeneity indicates that the support (or mass) points for the two types are generally significantly different from each other. The estimated proportion of type 1 individuals varies from 96 percent for non-refugee women to 18 percent for refugee men. For natives, the proportions are 55 percent for men and 46 percent for women.

While the estimates reported above indicate the direction of the effect of changes in observable characteristics on the hazard rates, the non-linear nature of the model makes it difficult to assess the magnitude of these effects. One way to illustrate the effect of background characteristics on the exit and entry probabilities is to simulate these transition rates for a synthetic cohort. The parameter estimates from the model along with the stochastic assumptions that are made on the unobservables are used to generate values of the latent variables that underlie the hazard function. Specifically, the two following latent variables

$$
I_{h t}^{E P}=\widehat{\mu}_{h}^{E P}+\mathbf{X}_{h, t-1} \widehat{\beta}^{E P}+\hat{\gamma}^{E P}\left(d_{h, t-1}\right)+\varepsilon_{h t}^{E P}
$$

and

$$
I_{h t}^{E N P}=\hat{\mu}_{h}^{E N P}+\mathbf{X}_{h, t-1} \widehat{\beta}^{E N P}+\hat{\gamma}^{E N P}\left(d_{h, t-1}\right)+\varepsilon_{h t}^{E N P}
$$


were generated for 10,000 synthetic households who were just beginning a poverty spell, holding the observable characteristics constant, for 10 time periods. $\hat{\mu}_{h}^{E P}$ and $\hat{\mu}_{h}^{E N P}$ were estimated as $\hat{\mu}_{h}^{E P}(1) * \hat{\pi}_{1}+\hat{\mu}_{h}^{E P}(2) * \hat{\pi}_{2}$ and $\hat{\mu}_{h}^{E N P}(1) * \hat{\pi}_{1}+\hat{\mu}_{h}^{E N P}(2) * \hat{\pi}_{2}$, respectively. Finally, $\varepsilon_{h t}^{E P}$ and $\varepsilon_{h t}^{E N P}$ were obtained from i.i.d. random draws from a standard normal distribution. A transition from poverty occurs when $I_{h t}^{E P}$ is positive and a re-entry into poverty occurs when $I_{h t}^{E N P}$ is positive.

The results from the simulations are presented in Tables 8 and 9. The first set of rows (Panel A) describe number of years in poverty as well as the fraction experiencing 5 years or more in poverty out of the next ten for a household who was poor in the initial period, whose representative is 25 years old initially, has no schooling beyond primary school, is single, has no children and lives in an urban region with a local unemployment rate of 5 percent. For native men, the average number of years spent poor out of the next ten is 3.8 years, and it is 3.6 years among refugee immigrants and 4.8 years among nonrefugee immigrants. The fraction of these households that experience more than 4 years in poverty is 26 percent for natives, 19 percent for refugees, and 28 percent for nonrefugees. Increasing the schooling level reduces both average years as well as the proportion with poverty more than 4 years in all three groups, but more so for natives than for immigrants. An increase in the local unemployment rate from 5 percent to 10 percent increases average years and the proportion substantially for all three groups. Average years increase to 4.8 years for natives, 5 years for refugees, and 5.2 years for non-refugees. Presence of children also increase the average time spent in poverty, especially for immigrant households, regardless of marital status. Average years for a one-parent household with two children are: 4.2 years for natives, 4.6 years for refugees, and 4.5 years for non-refugees. For two-parent households with two children these numbers are: 5.1 years for natives, 6.3 years for refugees, and 5.7 years for non-refugees.

The second panel in the table (Panel B) shows results for households that are similar to those in Panel A, apart from the initial age, which is now set to 45 instead of 25. In all 
cases, the increased initial age implies substantially shorter time spent in poverty. This clearly illustrates that the probabilities of leaving and re-entering poverty are reduced with age. This can partly be explained by increased labor market experience, which increase both employment probabilities and wage offers. To summarize, the exit rates are lowest and the recidivism rates are highest among households with children, particularly immigrant households with children. Improved labor market conditions and increased educational attainment increase exit rates and reduce recidivism.

We also used the simulations to illustrate years out of poverty by instead setting the initial condition to non-poor. These results are shown in columns 3, 4, 7, 8, 11, and 12. For native men, with initial age of 25, the average years out of poverty range between 9.8 and 9.9 years, depending on educational level. For refugees and non-refugees, time out of poverty is lower, between 8.9 years and 9.4 years, depending on education. Increases in the local unemployment rate substantially reduce time out of non-poverty for all groups, but more so for immigrants. Finally, there is a strong impact of children on years out of poverty with large decreases for all groups. Again, the effect is stronger among immigrants than among natives. Panel B shows years out of poverty for households whose initial age 45 instead of 25. In all cases, the increased initial age implies substantially longer time spent out of poverty.

The simulation results for men in Table 8 illustrate the reasons for the difference in poverty rates between natives and immigrants. While there are only small differences between natives and immigrants in years in poverty for households without children, immigrant households with children experience more poverty than similar native households. Given that immigrant household have more children on average than native household, we find that immigrants to a greater extent than natives remain in poverty.

The results for women are presented in Table 9. The first entries in Panel A shows that the average number of years spent poor out of the next ten, conditioning on being poor initially, is 2.8 years for natives, 5.2 years among refugee immigrants and 3.5 years among non-refugee immigrants. The fraction of these households that experience more 
than 4 years in poverty is 12 percent for natives, 42 percent for refugees, and 22 percent for non-refugees. Increasing the schooling level reduces both average years as well as the proportion with poverty more than 4 years in all three groups. An increase in the local unemployment rate from 5 percent to 10 percent increases average years and the proportion substantially for natives, but has only a minor effect for immigrant women. Average years increase to 3.5 years for natives, 5.4 years for refugees, and 3.7 years for non-refugees. Presence of children also increase the average time spent in poverty, especially for native households, regardless of marital status. Average years for a single adult household with two children are: 5.6 years for natives, 5.6 years for refugees, and 5.4 years for non-refugees. For households with two adults and two children these numbers are: 6.0 years for natives, 6.7 years for refugees, and 5.4 years for non-refugees.

The second panel in the table (Panel B) shows results for households that similar to those in Panel A, apart from the initial age. As for men, the increased initial age implies substantially shorter time spent in poverty. Again, this provides a clear indication that the probabilities of leaving and re-entering poverty are reduced with age. To summarize the results for women, we find differences in exit rates recidivism rates between natives and immigrants among single and unattached women. We also find, similar to the results for men, that exit rates are lowest and recidivism rates are highest among households with children. However, as opposed to the male results in Table 8, there are no major differences between natives and immigrants among families with children. These results also suggest that while improved labor market conditions increase exit rates for natives, it has less impact on exit rates for immigrants. Finally, increased educational attainment substantially reduces time spent poor, especially among refugee women.

Regarding years out of poverty (shown in columns 3, 4, 7, 8, 11, and 12) we find that for native and non-refugee women, with initial age of 25 , the average years out of poverty was 9.8 to 9.9 years, regardless of educational level. For refugees, time out of poverty is lower, between 9.1 years and 9.6 years, depending on education. Increases in the unemployment rate reduce time out of poverty for all groups, but more so for refugee women. Finally, there is a strong impact of children on years out of poverty with large 
decreases for all groups. Contrary to the results for men, the effect of children is similar across immigrant groups. Panel B shows years out of poverty for households whose initial age 45 instead of 25. In all cases, the increased initial age implies substantially longer time spent out of poverty.

The simulation results for women in Table 9 provide a slightly different picture of the native-immigrant poverty gap. While we found relatively small differences in poverty between native and immigrant single, unattached male households, this is not true for female households. Among refugee women, the average number of years poor out of the next ten is approximately twice that of native women. Increases in education and unemployment rate reduce this difference only slightly. However, among families with children, there are no major differences in years poor across the immigrant groups. This contrast the results found for men, where immigrant households with children experience more poverty than similar native households. Overall, the risk of becoming poor and remaining poor, conditioning on being poor in the initial state, is greater among immigrants than natives. This suggests that while policies designed to combat poverty by increasing the chance of leaving poverty among the poor will benefit all immigrant groups, reducing the risk of becoming poor may have larger affects among the immigrant population than among natives. This result is also illustrated in Figures 3 and 4, which shows that the transition rates into poverty is substantially higher for refugee immigrants than for natives, even if the difference was reduced between 1992 and 2001, especially for men.

During the first half of the 1990s, Sweden experienced a dramatic increase in refugee immigration, predominantly from the Balkan countries. While annual immigration since the World War II has amounted to about 0.4 percent of the population, this fraction was close to 1 percent between 1991 and 1995. This development altered the composition of the immigrant population in Sweden and in an attempt to explore the robustness of our findings to this change in the stock of immigrants, we constructed an unbalanced panel for the refugee immigrants and re-estimated our model on this new sample. The data used for the results presented above only included households who were residing in Sweden 
all years between 1991 and 2001, and recent refugee immigrants were therefore excluded from that sample. The results for refugees based on the unbalanced sample, in which we required households to be observed for at least three periods out the 11 possible, are presented in Table 3A in appendix. Overall, the results based on the sample that includes recent immigrant are quite similar to those from a sample which excludes these immigrants. The average number of years in poverty out of the next ten, conditioning on being poor initially, is only slightly higher in the sample that includes refugee immigrants that arrived during the 1990s.

\section{Conclusions}

This paper analyzes poverty persistence in Sweden using data from a large representative Swedish panel data set, LINDA, for the years 1991 to 2001. The data contains detailed information on household disposable income obtained from individual tax files and poverty is defined using information on annual minimum needs standards determined by the Swedish National Board of Health and Welfare. The unadjusted data indicates that poverty rates are higher for immigrants, especially refugee immigrants, than for natives. Further, family composition is also strongly correlated with poverty - regardless of immigrant status - and poverty rates are higher among single adult households, and among households with children. Furthermore, immigrant households and households with children appear to be more likely to remain in poverty in consecutive years and are also more likely to enter poverty in a given year, given that the household was non-poor in the previous year. We find evidence of substantial differences between immigrants from refugee countries and natives, but smaller differences between non-refugee immigrants and natives.

Central to the current poverty debate is the issue of an existence of a "poverty trap". That is, whether poverty is a condition that affects relatively few households, but those affected remains in poverty for a large portion of their lifetimes. Poverty persistence can be due to the fact that being poor today has a direct and "true" effect on the probability of being poor in the next period. Alternatively, the observed persistence might be driven by 
unobserved factors, such as preferences and labor market ability. An understanding of the dynamic aspects of poverty is essential from a policy perspective since different policies are more likely to be effective depending on the nature of poverty. Gaining insight about the flows into and out-of poverty allows a better description of the poor in any given year and also identifies groups that need to be targeted by poverty reducing policies. If poverty dynamics are described by a high incidence of becoming poor in conjunction with high exit probabilities, short-term income support programs are appropriate. On the other hand, if poverty is a condition experienced only by a small sub-population but with high persistence, there is a stronger need for active programs designed to improve long-term labor market outcomes for this group. The empirical model that we implement in this paper, a hazard rate model based on multiple spells that also accounts for unobserved heterogeneity and possibly endogenous initial conditions, is designed to provide us with consistent estimates of poverty persistence. These estimates can then be used to determine nature of poverty in Sweden.

The empirical results suggest existence of substantial poverty persistence. We divided our sample into six categories depending on the gender and immigrant status of the person representing the household, and we find evidence of significant, negative duration dependence for all these groups. The use of multiple poverty spells clearly show that total time in poverty can be seriously underestimated in single-spell models. For male singleadult households with no children, we find that natives spend 3-4 years in poverty out of the next ten conditioning on being poor initially, depending on educational attainment. Similar results were obtained for refugee and non-refugee immigrants. Among male represented households with children, regardless of marital status, expected years in poverty are higher for both natives (4-5 years) and immigrants (5-6 years). For female single-adult households with no children, natives spend between 2-3 years in poverty out of the next ten, again conditioning on being poor initially and depending on educational attainment. The figures for immigrant women are higher, 3-5 years for refugee women and 3-4 years for non-refugee women. Looking at female represented households with children, natives spend about 6 years in poverty out of the next ten, refugees spend 6-7 years in poverty and non-refugees spend 5.4 years in poverty. Thus, the family types that 
appear to be "trapped" in poverty are households with children present, regardless of whether it is a single-parent or a two-parent household. Further, among these households, immigrant families spend more time in poverty than similar native families.

The results suggest that poverty is a condition experienced mostly by a small subpopulation but with high persistence. The groups that are most vulnerable and that have both low exit probabilities and high entry probabilities are households with children and immigrant households. Short-term income support programs - such as social assistance, and child- and housing allowances - might not be sufficient to permanently move these groups out of poverty. Instead, more emphasis should be placed on programs that are designed to improve long-term labor market outcomes for these groups. 


\section{References}

Bane, Mary Jo, and David Ellwood. 1986. "Slipping Into and Out of Poverty: The Dynamics of Spells,” Journal of Human Resources 21(1):1-23.

Biewen, Martin. 2003. "Who are the Chronic Poor? Evidence on the Extent and the Composition of Chronic Poverty in Germany,” IZA Discussion Paper, No. 779, Institute for Study of Labor, Bonn.

Cameron, Stephen, and James Heckman. 2001. "The Dynamics of Educational Attainment for Black, Hispanic, and White Males,” Journal of Political Economy 109(3):455-499.

Cappellari, Lorenzo, and Stephen Jenkins. 2002. "Who Stays Poor? Who Becomes Poor? Evidence from the British Household Panel Survey,” The Economic Journal 112(March):C60-C67.

Devicienti, Francesco. 2001. "Estimating Poverty Persistence in Britain,” LRR Working Papers Series, No. 1, Centre for Employment Studies, Torino.

Eberwein, Curtis, John Ham, and Robert Lalonde. 1997. “The Impact of Being Offered and Receiving Classroom Training on the Employment Histories of Disadvantaged Women: Evidence from Experimental Data,” Review of Economic Studies 64(4):655-682.

Edin, Per-Anders, and Peter Fredriksson. 2000. "LINDA - Longitudinal Individual Data for Sweden,” Working Paper, Uppsala University.

Finnie, Ross, and Arthur Sweetman. 2003. "Poverty Dynamics: Empirical Evidence for Canada,” Canadian Journal of Economics 36(2):291-335.

Halleröd, Björn. 1999. "Fattigdom i Sverige,” Rapport från arbetsgruppen för ekonomisk trygghet till Nationella folkhälsokommitéen. 
Ham, John, and Robert Lalonde. 1996. “The Effect of Sample Selection and Initial Conditions in Duration Models: Evidence from Experimental Data on Training,” Econometrica 64(1):175-205.

Hansen, Jorgen, and Magnus Lofstrom. 2001. “The Dynamics of Immigrant Welfare and Labor Market Behavior,” IZA Discussion Paper, No. 360, Institute for Study of Labor, Bonn.

Heckman, James. 1981. “The Incidental Parameters Problem and the Problem of Initial Conditions in Estimating a Discrete Time - Discrete Data Stochastic Process,” In Manski, Charles, and Daniel McFadden. (Eds.), Structural Analysis of Discrete Data with Econometric Applications, MIT Press, Cambridge, MA, 179-195.

Heckman, James, and Burton Singer. 1984. “A Method for Minimizing the Impact of Distributional Assumption in Econometric Models for Duration Data,” Econometrica 52(2):271-320.

Lillard, Lee, and Robert Willis. 1978. "Dynamic Aspects of Earnings Mobility,” Econometrica 46(5):985-1012.

Ministry of Finance. 2003. Government Proposition 2002/03:100, Bilaga 3.

National Board of Health and Welfare. 2001. Välfärdsbokslut för 1990-talet. SOU 2001:79.

Stevens, Ann Huff. 1994. “The Dynamics of Poverty Spells: Updating Bane and Ellwood,” American Economic Review 84(2):34-37.

Stevens, Ann Huff. 1999. “Climbing Out of Poverty, Falling Back In,” Journal of Human Resources 34(3):557-588. 
Oxley Howard, Thai Thanh Dang, and Pablo Antolín. 2000. "Poverty Dynamics in Six OECD Countries,” OECD Economic Studies No. 30:7-32. 
Table 1. Descriptive Statistics for Men, by Immigrant Group.

\begin{tabular}{|c|c|c|c|}
\hline & Native & Refugee & Non-refugee \\
\hline Variable & $\begin{array}{c}\text { Mean } \\
\text { (Std. dev.) }\end{array}$ & $\begin{array}{c}\text { Mean } \\
\text { (Std. dev.) }\end{array}$ & $\begin{array}{c}\text { Mean } \\
\text { (Std. dev.) }\end{array}$ \\
\hline Age & $\begin{array}{l}44.59 \\
(9.34)\end{array}$ & $\begin{array}{l}43.09 \\
(8.58)\end{array}$ & $\begin{array}{l}44.54 \\
(8.42)\end{array}$ \\
\hline Number of children & $\begin{array}{l}0.80 \\
(1.07)\end{array}$ & $\begin{array}{c}1.02 \\
(1.26)\end{array}$ & $\begin{array}{l}0.73 \\
(1.06)\end{array}$ \\
\hline Years since arrival & - & $\begin{array}{l}14.61 \\
(7.03)\end{array}$ & $\begin{array}{l}20.06 \\
(7.37)\end{array}$ \\
\hline Arrived 1968-1975 & - & 0.19 & 0.55 \\
\hline Arrived 1976-1980 & - & 0.24 & 0.21 \\
\hline Arrived 1981-1985 & - & 0.23 & 0.11 \\
\hline Arrived 1986-1990 & - & 0.34 & 0.13 \\
\hline Single & 0.33 & 0.36 & 0.41 \\
\hline Compulsory school & 0.26 & 0.28 & 0.37 \\
\hline High school & 0.49 & 0.49 & 0.46 \\
\hline University & 0.25 & 0.24 & 0.17 \\
\hline $\begin{array}{l}\text { Residing in large-sized } \\
\text { cities }\end{array}$ & 0.32 & 0.68 & 0.50 \\
\hline $\begin{array}{l}\text { Residing in medium- } \\
\text { sized cities }\end{array}$ & 0.45 & 0.24 & 0.31 \\
\hline $\begin{array}{l}\text { Residing in the } \\
\text { countryside }\end{array}$ & 0.23 & 0.08 & 0.19 \\
\hline Proportion being poor & 0.08 & 0.25 & 0.14 \\
\hline $\begin{array}{l}\text { Local unemployment } \\
\text { rate }\end{array}$ & $\begin{array}{c}6.78 \\
(1.70)\end{array}$ & $\begin{array}{c}6.86 \\
(1.73)\end{array}$ & $\begin{array}{c}6.83 \\
(1.83)\end{array}$ \\
\hline Number of individuals & 28,989 & 816 & 1,426 \\
\hline Number of observations & 318,879 & 8,976 & 15,686 \\
\hline
\end{tabular}

Note: Standard deviations appear in parentheses. 
Table 2. Descriptive Statistics for Women, by Immigrant Group.

\begin{tabular}{|c|c|c|c|}
\hline & Native & Refugee & Non-refugee \\
\hline Variable & $\begin{array}{c}\text { Mean } \\
\text { (Std. dev.) }\end{array}$ & $\begin{array}{c}\text { Mean } \\
\text { (Std. dev.) }\end{array}$ & $\begin{array}{c}\text { Mean } \\
\text { (Std. dev.) }\end{array}$ \\
\hline Age & $\begin{array}{l}45.65 \\
(9.26)\end{array}$ & $\begin{array}{l}43.37 \\
(8.98)\end{array}$ & $\begin{array}{l}44.55 \\
(8.04)\end{array}$ \\
\hline Number of children & $\begin{array}{c}0.77 \\
(1.04)\end{array}$ & $\begin{array}{l}1.00 \\
(1.13)\end{array}$ & $\begin{array}{l}0.80 \\
(1.04)\end{array}$ \\
\hline Years since arrival & - & $\begin{array}{l}15.18 \\
(6.77)\end{array}$ & $\begin{array}{l}20.48 \\
(7.24)\end{array}$ \\
\hline Arrived 1968-1975 & - & 0.19 & 0.56 \\
\hline Arrived 1976-1980 & - & 0.27 & 0.21 \\
\hline Arrived 1981-1985 & - & 0.27 & 0.11 \\
\hline Arrived 1986-1990 & - & 0.27 & 0.12 \\
\hline Single & 0.30 & 0.34 & 0.37 \\
\hline Compulsory school & 0.23 & 0.29 & 0.33 \\
\hline High school & 0.50 & 0.45 & 0.43 \\
\hline University & 0.27 & 0.25 & 0.24 \\
\hline $\begin{array}{l}\text { Residing in large-sized } \\
\text { cities }\end{array}$ & 0.33 & 0.61 & 0.52 \\
\hline $\begin{array}{l}\text { Residing in medium- } \\
\text { sized cities }\end{array}$ & 0.45 & 0.28 & 0.30 \\
\hline $\begin{array}{l}\text { Residing in the } \\
\text { countryside }\end{array}$ & 0.22 & 0.11 & 0.18 \\
\hline Proportion being poor & 0.08 & 0.20 & 0.10 \\
\hline $\begin{array}{l}\text { Local unemployment } \\
\text { rate }\end{array}$ & $\begin{array}{l}5.46 \\
(1.20)\end{array}$ & $\begin{array}{c}5.56 \\
(1.33)\end{array}$ & $\begin{array}{c}5.36 \\
(1.29)\end{array}$ \\
\hline Number of individuals & 27,510 & 681 & 1,282 \\
\hline Number of observations & 302,610 & 7,491 & 14,102 \\
\hline
\end{tabular}

Note: Standard deviations appear in parentheses. 
Table 3. Distribution of Years Spent Poor for Males Using Single and Multiple Spells, by Immigrant Group.

\begin{tabular}{ccccccc}
\hline & \multicolumn{2}{c}{ Native } & \multicolumn{2}{c}{ Refugee } & \multicolumn{2}{c}{ Non-Refugee } \\
\hline \multirow{2}{*}{ Years Poor } & $\begin{array}{c}\text { Single } \\
\text { Spell }\end{array}$ & $\begin{array}{c}\text { Multiple } \\
\text { Spell }\end{array}$ & $\begin{array}{c}\text { Single } \\
\text { Spell }\end{array}$ & $\begin{array}{c}\text { Multiple } \\
\text { Spell }\end{array}$ & $\begin{array}{c}\text { Single } \\
\text { Spell }\end{array}$ & $\begin{array}{c}\text { Multiple } \\
\text { Spell }\end{array}$ \\
\hline & & & & & & \\
1 & 0.342 & 0.230 & 0.282 & 0.165 & 0.333 & 0.207 \\
2 & 0.161 & 0.146 & 0.156 & 0.115 & 0.144 & 0.128 \\
3 & 0.105 & 0.118 & 0.084 & 0.091 & 0.099 & 0.122 \\
4 & 0.070 & 0.099 & 0.067 & 0.084 & 0.065 & 0.072 \\
5 & 0.056 & 0.077 & 0.060 & 0.077 & 0.056 & 0.077 \\
6 & 0.055 & 0.078 & 0.034 & 0.072 & 0.038 & 0.059 \\
7 & 0.063 & 0.074 & 0.067 & 0.074 & 0.061 & 0.077 \\
8 & 0.040 & 0.052 & 0.062 & 0.086 & 0.045 & 0.063 \\
9 & 0.034 & 0.042 & 0.043 & 0.053 & 0.038 & 0.068 \\
10 & 0.032 & 0.041 & 0.046 & 0.084 & 0.027 & 0.036 \\
11 & 0.042 & 0.042 & 0.101 & 0.101 & 0.092 & 0.092 \\
& & & & & & \\
E(Years) & 3.7 & 4.3 & 4.5 & 5.4 & 4.1 & 4.9 \\
\hline
\end{tabular}

Table 4. Distribution of Years Spent Poor for Females Using Single and Multiple Spells, by Immigrant Group.

\begin{tabular}{ccccccc}
\hline \multicolumn{9}{c}{ Native } & \multicolumn{2}{c}{ Refugee } & \multicolumn{2}{c}{ Non-Refugee } \\
\hline & $\begin{array}{c}\text { Single } \\
\text { Years Poor } \\
\text { Spell }\end{array}$ & $\begin{array}{c}\text { Multiple } \\
\text { Spell }\end{array}$ & $\begin{array}{c}\text { Single } \\
\text { Spell }\end{array}$ & $\begin{array}{c}\text { Multiple } \\
\text { Spell }\end{array}$ & $\begin{array}{c}\text { Single } \\
\text { Spell }\end{array}$ & $\begin{array}{c}\text { Multiple } \\
\text { Spell }\end{array}$ \\
\hline & & & & & & \\
1 & 0.329 & 0.220 & 0.305 & 0.176 & 0.345 & 0.222 \\
2 & 0.146 & 0.134 & 0.143 & 0.125 & 0.147 & 0.114 \\
3 & 0.096 & 0.107 & 0.072 & 0.090 & 0.108 & 0.120 \\
4 & 0.069 & 0.088 & 0.068 & 0.086 & 0.068 & 0.094 \\
5 & 0.057 & 0.078 & 0.054 & 0.093 & 0.059 & 0.075 \\
6 & 0.056 & 0.076 & 0.036 & 0.061 & 0.049 & 0.088 \\
7 & 0.076 & 0.088 & 0.065 & 0.068 & 0.029 & 0.049 \\
8 & 0.049 & 0.060 & 0.047 & 0.054 & 0.036 & 0.049 \\
9 & 0.038 & 0.054 & 0.036 & 0.050 & 0.023 & 0.042 \\
10 & 0.033 & 0.044 & 0.050 & 0.072 & 0.033 & 0.042 \\
11 & 0.050 & 0.050 & 0.125 & 0.125 & 0.104 & 0.104 \\
& & & & & & \\
E(Years) & 4.0 & 4.6 & 4.6 & 5.3 & 4.0 & 4.8 \\
\hline
\end{tabular}


Table 5. Distribution of Years Spent Poor for both Males and Females Using Multiple Spells, by Immigrant Group.

\begin{tabular}{|c|c|c|c|c|c|c|}
\hline \multirow[b]{2}{*}{ Years Poor } & \multicolumn{2}{|c|}{ Native } & \multicolumn{2}{|c|}{ Refugee } & \multicolumn{2}{|c|}{ Non-Refugee } \\
\hline & Males & Females & Males & Females & Males & Females \\
\hline 0 & 0.784 & 0.802 & 0.488 & 0.590 & 0.689 & 0.761 \\
\hline 1 & 0.050 & 0.044 & 0.085 & 0.072 & 0.064 & 0.053 \\
\hline 2 & 0.032 & 0.026 & 0.059 & 0.051 & 0.040 & 0.027 \\
\hline 3 & 0.026 & 0.021 & 0.047 & 0.037 & 0.038 & 0.029 \\
\hline 4 & 0.021 & 0.018 & 0.043 & 0.035 & 0.022 & 0.023 \\
\hline 5 & 0.017 & 0.016 & 0.039 & 0.038 & 0.024 & 0.018 \\
\hline 6 & 0.017 & 0.015 & 0.037 & 0.025 & 0.018 & 0.021 \\
\hline 7 & 0.016 & 0.018 & 0.038 & 0.028 & 0.024 & 0.012 \\
\hline 8 & 0.011 & 0.012 & 0.044 & 0.022 & 0.020 & 0.012 \\
\hline 9 & 0.009 & 0.011 & 0.027 & 0.021 & 0.021 & 0.010 \\
\hline 10 & 0.009 & 0.009 & 0.043 & 0.029 & 0.011 & 0.010 \\
\hline 11 & 0.009 & 0.010 & 0.052 & 0.051 & 0.029 & 0.025 \\
\hline $\mathrm{E}($ Years $)$ & 0.9 & 0.9 & 2.8 & 2.2 & 1.5 & 1.1 \\
\hline
\end{tabular}


Table 6. Coefficients from Maximum Likelihood Estimation of Hazard Rates with Unobserved Heterogeneity.

\begin{tabular}{|c|c|c|c|c|c|c|c|c|c|}
\hline \multicolumn{10}{|c|}{ Men } \\
\hline \multirow[b]{2}{*}{ Variable } & \multicolumn{3}{|c|}{ Native } & \multicolumn{3}{|c|}{ Refugee } & \multicolumn{3}{|c|}{ Non-refugee } \\
\hline & $\begin{array}{c}\text { Initial } \\
\text { condition }\end{array}$ & $\begin{array}{c}\text { Exit } \\
\text { Poverty }\end{array}$ & $\begin{array}{c}\text { Enter } \\
\text { Poverty } \\
\end{array}$ & $\begin{array}{c}\text { Initial } \\
\text { condition }\end{array}$ & $\begin{array}{c}\text { Exit } \\
\text { Poverty }\end{array}$ & $\begin{array}{c}\text { Enter } \\
\text { Poverty }\end{array}$ & $\begin{array}{c}\text { Initial } \\
\text { condition }\end{array}$ & $\begin{array}{c}\text { Exit } \\
\text { Poverty }\end{array}$ & $\begin{array}{c}\text { Enter } \\
\text { Poverty }\end{array}$ \\
\hline Single & $\begin{array}{c}0.90 \\
(0.06)\end{array}$ & $\begin{array}{l}-0.82 \\
(0.05)\end{array}$ & $\begin{array}{c}0.04 \\
(0.03)\end{array}$ & $\begin{array}{c}0.65 \\
(0.25)\end{array}$ & $\begin{array}{l}-0.38 \\
(0.14)\end{array}$ & $\begin{array}{c}0.04 \\
(0.10)\end{array}$ & $\begin{array}{c}1.19 \\
(0.26)\end{array}$ & $\begin{array}{l}-0.57 \\
(0.13)\end{array}$ & $\begin{array}{c}0.46 \\
(0.10)\end{array}$ \\
\hline High school & $\begin{array}{l}-0.22 \\
(0.03)\end{array}$ & $\begin{array}{c}0.14 \\
(0.03)\end{array}$ & $\begin{array}{l}-0.07 \\
(0.02)\end{array}$ & $\begin{array}{c}0.09 \\
(0.19)\end{array}$ & $\begin{array}{c}0.00 \\
(0.09)\end{array}$ & $\begin{array}{l}-0.07 \\
(0.08)\end{array}$ & $\begin{array}{c}0.06 \\
(0.16)\end{array}$ & $\begin{array}{c}0.07 \\
(0.08)\end{array}$ & $\begin{array}{c}0.01 \\
(0.07)\end{array}$ \\
\hline University & $\begin{array}{l}-0.75 \\
(0.04)\end{array}$ & $\begin{array}{c}0.22 \\
(0.03)\end{array}$ & $\begin{array}{l}-0.37 \\
(0.02)\end{array}$ & $\begin{array}{l}-0.60 \\
(0.24)\end{array}$ & $\begin{array}{c}0.22 \\
(0.11)\end{array}$ & $\begin{array}{l}-0.26 \\
(0.10)\end{array}$ & $\begin{array}{l}-0.25 \\
(0.22)\end{array}$ & $\begin{array}{c}0.01 \\
(0.11)\end{array}$ & $\begin{array}{l}-0.19 \\
(0.09)\end{array}$ \\
\hline \# Children & $\begin{array}{l}1.06 \\
(0.02)\end{array}$ & $\begin{array}{l}-0.46 \\
(0.01)\end{array}$ & $\begin{array}{l}0.47 \\
(0.01)\end{array}$ & $\begin{array}{c}1.12 \\
(0.14)\end{array}$ & $\begin{array}{l}-0.43 \\
(0.05)\end{array}$ & $\begin{array}{c}0.37 \\
(0.05)\end{array}$ & $\begin{array}{c}1.21 \\
(0.13)\end{array}$ & $\begin{array}{l}-0.29 \\
(0.05)\end{array}$ & $\begin{array}{c}0.50 \\
(0.05)\end{array}$ \\
\hline \# Children*Single & $\begin{array}{l}-0.56 \\
(0.07)\end{array}$ & $\begin{array}{c}0.52 \\
(0.04)\end{array}$ & $\begin{array}{l}-0.09 \\
(0.03)\end{array}$ & $\begin{array}{l}-0.67 \\
(0.27)\end{array}$ & $\begin{array}{c}0.44 \\
(0.10)\end{array}$ & $\begin{array}{l}-0.09 \\
(0.12)\end{array}$ & $\begin{array}{l}-1.41 \\
(0.47)\end{array}$ & $\begin{array}{c}0.47 \\
(0.12)\end{array}$ & $\begin{array}{l}-0.23 \\
(0.11)\end{array}$ \\
\hline Age & $\begin{array}{l}-1.33 \\
(0.20)\end{array}$ & $\begin{array}{l}1.47 \\
(0.16)\end{array}$ & $\begin{array}{l}-3.03 \\
(0.10)\end{array}$ & $\begin{array}{l}-0.05 \\
(1.11)\end{array}$ & $\begin{array}{c}1.66 \\
(0.59)\end{array}$ & $\begin{array}{l}-2.19 \\
(0.50)\end{array}$ & $\begin{array}{l}-1.76 \\
(1.13)\end{array}$ & $\begin{array}{c}0.68 \\
(0.56)\end{array}$ & $\begin{array}{l}-1.96 \\
(0.44)\end{array}$ \\
\hline Residing in large-sized cities & $\begin{array}{l}-0.34 \\
(0.04)\end{array}$ & $\begin{array}{c}0.08 \\
(0.03)\end{array}$ & $\begin{array}{l}-0.13 \\
(0.02)\end{array}$ & $\begin{array}{l}-0.11 \\
(0.29)\end{array}$ & $\begin{array}{l}-0.07 \\
(0.14)\end{array}$ & $\begin{array}{c}0.06 \\
(0.13)\end{array}$ & $\begin{array}{c}0.25 \\
(0.20)\end{array}$ & $\begin{array}{l}-0.09 \\
(0.10)\end{array}$ & $\begin{array}{c}0.12 \\
(0.08)\end{array}$ \\
\hline $\begin{array}{l}\text { Residing in medium-sized } \\
\text { cities }\end{array}$ & $\begin{array}{l}-0.24 \\
(0.03)\end{array}$ & $\begin{array}{l}0.09 \\
(0.02)\end{array}$ & $\begin{array}{l}-0.13 \\
(0.02)\end{array}$ & $\begin{array}{l}0.13 \\
(0.30)\end{array}$ & $\begin{array}{l}-0.16 \\
(0.15)\end{array}$ & $\begin{array}{l}-0.02 \\
(0.14)\end{array}$ & $\begin{array}{l}0.00 \\
(0.21)\end{array}$ & $\begin{array}{l}0.06 \\
(0.11)\end{array}$ & $\begin{array}{l}-0.00 \\
(0.09)\end{array}$ \\
\hline Local unemployment rate & $\begin{array}{l}0.45 \\
(0.08)\end{array}$ & $\begin{array}{l}-0.46 \\
(0.05)\end{array}$ & $\begin{array}{l}0.45 \\
(0.03)\end{array}$ & $\begin{array}{c}1.62 \\
(0.52)\end{array}$ & $\begin{array}{l}-0.69 \\
(0.17)\end{array}$ & $\begin{array}{c}0.52 \\
(0.15)\end{array}$ & $\begin{array}{l}0.82 \\
(0.37)\end{array}$ & $\begin{array}{c}0.01 \\
(0.15)\end{array}$ & $\begin{array}{c}0.51 \\
(0.12)\end{array}$ \\
\hline Durations (years) & & & & & & & & & \\
\hline 2 & - & $\begin{array}{l}-0.16 \\
(0.03)\end{array}$ & $\begin{array}{l}-0.20 \\
(0.02)\end{array}$ & - & $\begin{array}{l}-0.11 \\
(0.10)\end{array}$ & $\begin{array}{l}-0.32 \\
(0.09)\end{array}$ & - & $\begin{array}{l}-0.27 \\
(0.10)\end{array}$ & $\begin{array}{l}-0.27 \\
(0.09)\end{array}$ \\
\hline 3 & - & $\begin{array}{l}-0.15 \\
(0.03)\end{array}$ & $\begin{array}{l}-0.40 \\
(0.02)\end{array}$ & - & $\begin{array}{l}-0.17 \\
(0.12)\end{array}$ & $\begin{array}{l}-0.24 \\
(0.10)\end{array}$ & - & $\begin{array}{l}-0.40 \\
(0.11)\end{array}$ & $\begin{array}{l}-0.36 \\
(0.10)\end{array}$ \\
\hline 4 & - & $\begin{array}{l}-0.24 \\
(0.04)\end{array}$ & $\begin{array}{l}-0.38 \\
(0.03)\end{array}$ & - & $\begin{array}{l}-0.30 \\
(0.14)\end{array}$ & $\begin{array}{l}-0.31 \\
(0.12)\end{array}$ & - & $\begin{array}{l}-0.62 \\
(0.13)\end{array}$ & $\begin{array}{l}-0.38 \\
(0.11)\end{array}$ \\
\hline
\end{tabular}

\section{Continued...}




\section{Table 6 Continued:}

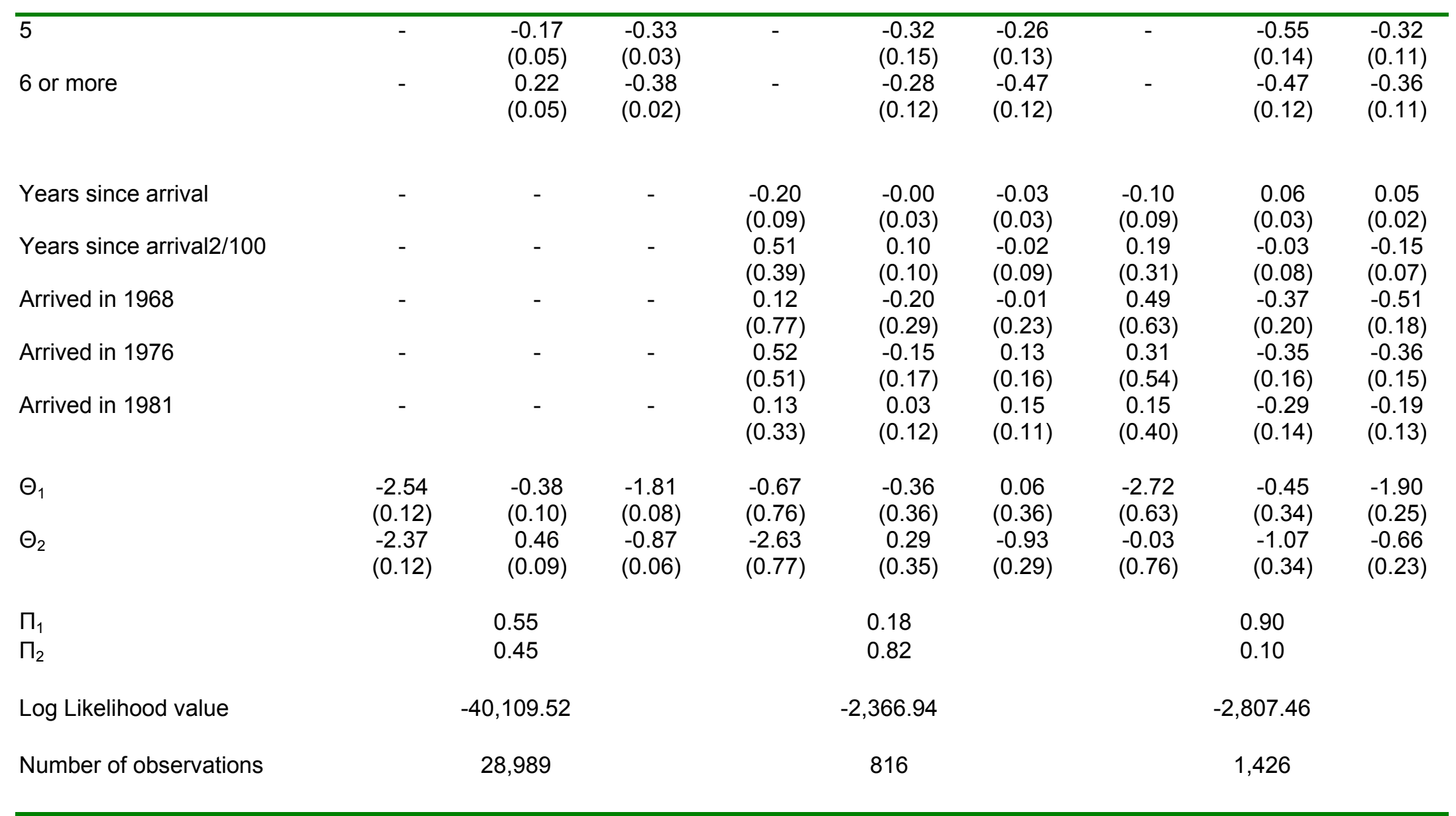

Note: Standard errors appear in parentheses. 
Table 7. Coefficients from Maximum Likelihood Estimation of Hazard Rates with Unobserved Heterogeneity.

\begin{tabular}{|c|c|c|c|c|c|c|c|c|c|}
\hline \multicolumn{10}{|c|}{ Women } \\
\hline \multirow[b]{2}{*}{ Variable } & \multicolumn{3}{|c|}{ Native } & \multicolumn{3}{|c|}{ Refugee } & \multicolumn{3}{|c|}{ Non-refugee } \\
\hline & $\begin{array}{c}\text { Initial } \\
\text { condition }\end{array}$ & $\begin{array}{c}\text { Exit } \\
\text { Poverty }\end{array}$ & $\begin{array}{c}\text { Enter } \\
\text { Poverty }\end{array}$ & $\begin{array}{c}\text { Initial } \\
\text { condition }\end{array}$ & $\begin{array}{c}\text { Exit } \\
\text { Poverty }\end{array}$ & $\begin{array}{c}\text { Enter } \\
\text { Poverty }\end{array}$ & $\begin{array}{c}\text { Initial } \\
\text { condition }\end{array}$ & $\begin{array}{c}\text { Exit } \\
\text { Poverty }\end{array}$ & $\begin{array}{c}\text { Enter } \\
\text { Poverty }\end{array}$ \\
\hline Single & $\begin{array}{c}0.54 \\
(0.06)\end{array}$ & $\begin{array}{l}-0.28 \\
(0.07)\end{array}$ & $\begin{array}{l}-0.20 \\
(0.03)\end{array}$ & $\begin{array}{l}-0.20 \\
(0.27)\end{array}$ & $\begin{array}{l}-1.33 \\
(0.22)\end{array}$ & $\begin{array}{l}-0.19 \\
(0.17)\end{array}$ & $\begin{array}{c}0.60 \\
(0.23)\end{array}$ & $\begin{array}{l}-0.46 \\
(0.28)\end{array}$ & $\begin{array}{l}-0.18 \\
(0.15)\end{array}$ \\
\hline High school & $\begin{array}{l}-0.21 \\
(0.04)\end{array}$ & $\begin{array}{c}0.18 \\
(0.03)\end{array}$ & $\begin{array}{l}-0.12 \\
(0.02)\end{array}$ & $\begin{array}{l}-0.17 \\
(0.17)\end{array}$ & $\begin{array}{c}0.28 \\
(0.11)\end{array}$ & $\begin{array}{l}-0.39 \\
(0.12)\end{array}$ & $\begin{array}{l}-0.08 \\
(0.14)\end{array}$ & $\begin{array}{c}0.12 \\
(0.12)\end{array}$ & $\begin{array}{l}-0.23 \\
(0.08)\end{array}$ \\
\hline University & $\begin{array}{l}-0.62 \\
(0.04)\end{array}$ & $\begin{array}{c}0.27 \\
(0.04)\end{array}$ & $\begin{array}{l}-0.27 \\
(0.03)\end{array}$ & $\begin{array}{l}-0.21 \\
(0.20)\end{array}$ & $\begin{array}{c}0.48 \\
(0.15)\end{array}$ & $\begin{array}{l}-0.33 \\
(0.14)\end{array}$ & $\begin{array}{l}-0.23 \\
(0.16)\end{array}$ & $\begin{array}{c}0.22 \\
(0.13)\end{array}$ & $\begin{array}{l}-0.35 \\
(0.10)\end{array}$ \\
\hline \# Children & $\begin{array}{c}0.98 \\
(0.02)\end{array}$ & $\begin{array}{l}-0.47 \\
(0.02)\end{array}$ & $\begin{array}{c}0.44 \\
(0.01)\end{array}$ & $\begin{array}{c}0.83 \\
(0.11)\end{array}$ & $\begin{array}{l}-0.64 \\
(0.08)\end{array}$ & $\begin{array}{c}0.51 \\
(0.07)\end{array}$ & $\begin{array}{c}0.85 \\
(0.08)\end{array}$ & $\begin{array}{l}-0.33 \\
(0.07)\end{array}$ & $\begin{array}{c}0.49 \\
(0.05)\end{array}$ \\
\hline \# Children*Single & $\begin{array}{l}-0.25 \\
(0.04)\end{array}$ & $\begin{array}{c}0.21 \\
(0.03)\end{array}$ & $\begin{array}{c}0.12 \\
(0.02)\end{array}$ & $\begin{array}{c}0.03 \\
(0.16)\end{array}$ & $\begin{array}{c}0.71 \\
(0.10)\end{array}$ & $\begin{array}{l}-0.18 \\
(0.13)\end{array}$ & $\begin{array}{l}-0.25 \\
(0.13)\end{array}$ & $\begin{array}{c}0.25 \\
(0.11)\end{array}$ & $\begin{array}{c}0.12 \\
(0.09)\end{array}$ \\
\hline Age & $\begin{array}{l}-1.27 \\
(0.21)\end{array}$ & $\begin{array}{c}2.61 \\
(0.19)\end{array}$ & $\begin{array}{l}-3.34 \\
(0.12)\end{array}$ & $\begin{array}{l}-1.41 \\
(1.12)\end{array}$ & $\begin{array}{c}1.61 \\
(0.72)\end{array}$ & $\begin{array}{l}-3.33 \\
(0.76)\end{array}$ & $\begin{array}{l}-0.72 \\
(0.95)\end{array}$ & $\begin{array}{c}2.71 \\
(0.87)\end{array}$ & $\begin{array}{l}-1.14 \\
(0.57)\end{array}$ \\
\hline Residing in large-sized cities & $\begin{array}{l}-0.43 \\
(0.04)\end{array}$ & $\begin{array}{c}0.11 \\
(0.03)\end{array}$ & $\begin{array}{l}-0.16 \\
(0.02)\end{array}$ & $\begin{array}{c}0.70 \\
(0.26)\end{array}$ & $\begin{array}{l}-0.10 \\
(0.17)\end{array}$ & $\begin{array}{c}0.44 \\
(0.17)\end{array}$ & $\begin{array}{l}-0.27 \\
(0.16)\end{array}$ & $\begin{array}{c}0.11 \\
(0.12)\end{array}$ & $\begin{array}{l}-0.09 \\
(0.09)\end{array}$ \\
\hline $\begin{array}{l}\text { Residing in medium-sized } \\
\text { cities }\end{array}$ & $\begin{array}{l}-0.23 \\
(0.03)\end{array}$ & $\begin{array}{l}0.05 \\
(0.03)\end{array}$ & $\begin{array}{l}-0.10 \\
(0.02)\end{array}$ & $\begin{array}{l}0.59 \\
(0.28)\end{array}$ & $\begin{array}{l}-0.10 \\
(0.18)\end{array}$ & $\begin{array}{l}0.22 \\
(0.18)\end{array}$ & $\begin{array}{l}-0.26 \\
(0.17)\end{array}$ & $\begin{array}{l}0.06 \\
(0.13)\end{array}$ & $\begin{array}{l}-0.06 \\
(0.10)\end{array}$ \\
\hline Local unemployment rate & $\begin{array}{l}0.18 \\
(0.09)\end{array}$ & $\begin{array}{l}-0.46 \\
(0.06)\end{array}$ & $\begin{array}{c}0.47 \\
(0.04)\end{array}$ & $\begin{array}{l}0.20 \\
(0.44)\end{array}$ & $\begin{array}{l}-0.03 \\
(0.23)\end{array}$ & $\begin{array}{c}0.27 \\
(0.22)\end{array}$ & $\begin{array}{l}0.77 \\
(0.37)\end{array}$ & $\begin{array}{l}-0.00 \\
(0.25)\end{array}$ & $\begin{array}{c}0.54 \\
(0.19)\end{array}$ \\
\hline Durations (years) & & & & & & & & & \\
\hline 2 & - & $\begin{array}{l}-0.23 \\
(0.03)\end{array}$ & $\begin{array}{l}-0.17 \\
(0.02)\end{array}$ & - & $\begin{array}{l}-0.24 \\
(0.13)\end{array}$ & $\begin{array}{l}-0.20 \\
(0.12)\end{array}$ & - & $\begin{array}{l}-0.36 \\
(0.12)\end{array}$ & $\begin{array}{l}-0.33 \\
(0.10)\end{array}$ \\
\hline 3 & - & $\begin{array}{l}-0.20 \\
(0.04)\end{array}$ & $\begin{array}{l}-0.35 \\
(0.03)\end{array}$ & - & $\begin{array}{l}-0.52 \\
(0.16)\end{array}$ & $\begin{array}{l}-0.37 \\
(0.15)\end{array}$ & - & $\begin{array}{l}-0.39 \\
(0.14)\end{array}$ & $\begin{array}{l}-0.55 \\
(0.12)\end{array}$ \\
\hline 4 & - & $\begin{array}{l}-0.32 \\
(0.04)\end{array}$ & $\begin{array}{l}-0.42 \\
(0.03)\end{array}$ & - & $\begin{array}{l}-0.57 \\
(0.18)\end{array}$ & $\begin{array}{l}-0.18 \\
(0.16)\end{array}$ & - & $\begin{array}{l}-0.53 \\
(0.16)\end{array}$ & $\begin{array}{l}-0.39 \\
(0.12)\end{array}$ \\
\hline
\end{tabular}

\section{Continued...}


Table 7 Continued:

\begin{tabular}{|c|c|c|c|c|c|c|c|c|c|}
\hline 5 & - & $\begin{array}{l}-0.25 \\
(0.05)\end{array}$ & $\begin{array}{l}-0.40 \\
(0.03)\end{array}$ & - & $\begin{array}{c}-0.53 \\
(0.19)\end{array}$ & $\begin{array}{l}-0.27 \\
(0.19)\end{array}$ & - & $\begin{array}{c}-0.43 \\
(0.18)\end{array}$ & $\begin{array}{c}-0.52 \\
(0.14)\end{array}$ \\
\hline 6 or more & - & $\begin{array}{c}0.21 \\
(0.04)\end{array}$ & $\begin{array}{l}-0.47 \\
(0.02)\end{array}$ & - & $\begin{array}{l}-0.53 \\
(0.15)\end{array}$ & $\begin{array}{l}-0.22 \\
(0.18)\end{array}$ & - & $\begin{array}{l}-0.65 \\
(0.17)\end{array}$ & $\begin{array}{c}-0.64 \\
(0.12)\end{array}$ \\
\hline Years since arrival & - & - & - & $\begin{array}{l}-0.21 \\
(0.09)\end{array}$ & $\begin{array}{c}0.13 \\
(0.04)\end{array}$ & $\begin{array}{l}-0.01 \\
(0.04)\end{array}$ & $\begin{array}{l}-0.18 \\
(0.10)\end{array}$ & $\begin{array}{c}0.06 \\
(0.03)\end{array}$ & $\begin{array}{l}-0.00 \\
(0.03)\end{array}$ \\
\hline Years since arrival2/100 & - & - & - & $\begin{array}{c}0.90 \\
(0.41)\end{array}$ & $\begin{array}{l}-0.25 \\
(0.13)\end{array}$ & $\begin{array}{c}0.01 \\
(0.11)\end{array}$ & $\begin{array}{c}0.49 \\
(0.29)\end{array}$ & $\begin{array}{l}-0.01 \\
(0.09)\end{array}$ & $\begin{array}{c}0.01 \\
(0.08)\end{array}$ \\
\hline Arrived in 1968 & - & - & - & $\begin{array}{c}-1.23 \\
(0.81)\end{array}$ & $\begin{array}{l}-0.54 \\
(0.36)\end{array}$ & $\begin{array}{c}-0.22 \\
(0.31)\end{array}$ & $\begin{array}{c}0.79 \\
(0.74)\end{array}$ & $\begin{array}{c}-0.72 \\
(0.27)\end{array}$ & $\begin{array}{c}-0.41 \\
(0.25)\end{array}$ \\
\hline Arrived in 1976 & - & - & - & $\begin{array}{l}-0.19 \\
(0.49)\end{array}$ & $\begin{array}{l}-0.34 \\
(0.22)\end{array}$ & $\begin{array}{l}-0.12 \\
(0.20)\end{array}$ & $\begin{array}{c}0.69 \\
(0.62)\end{array}$ & $\begin{array}{l}-0.35 \\
(0.22)\end{array}$ & $\begin{array}{c}-0.30 \\
(0.19)\end{array}$ \\
\hline Arrived in 1981 & - & - & - & $\begin{array}{l}-0.45 \\
(0.32)\end{array}$ & $\begin{array}{c}-0.12 \\
(0.16)\end{array}$ & $\begin{array}{l}-0.14 \\
(0.15)\end{array}$ & $\begin{array}{c}0.48 \\
(0.44)\end{array}$ & $\begin{array}{l}-0.58 \\
(0.20)\end{array}$ & $\begin{array}{c}-0.14 \\
(0.15)\end{array}$ \\
\hline$\Theta_{1}$ & $\begin{array}{l}-2.05 \\
(0.13)\end{array}$ & $\begin{array}{l}-1.00 \\
(0.11)\end{array}$ & $\begin{array}{l}-1.65 \\
(0.09)\end{array}$ & $\begin{array}{c}0.11 \\
(0.67)\end{array}$ & $\begin{array}{l}-1.12 \\
(0.43)\end{array}$ & $\begin{array}{c}0.04 \\
(0.47)\end{array}$ & $\begin{array}{l}-1.64 \\
(0.57)\end{array}$ & $\begin{array}{l}-1.13 \\
(0.50)\end{array}$ & $\begin{array}{c}-1.60 \\
(0.31)\end{array}$ \\
\hline$\Theta_{2}$ & $\begin{array}{l}-2.01 \\
(0.12)\end{array}$ & $\begin{array}{l}-0.13 \\
(0.11)\end{array}$ & $\begin{array}{c}-0.75 \\
(0.07)\end{array}$ & $\begin{array}{l}-1.02 \\
(0.67)\end{array}$ & $\begin{array}{l}-0.49 \\
(0.43)\end{array}$ & $\begin{array}{l}-1.10 \\
(0.41)\end{array}$ & $\begin{array}{c}0.53 \\
(0.64)\end{array}$ & $\begin{array}{l}-2.73 \\
(0.56)\end{array}$ & $\begin{array}{c}0.25 \\
(0.39)\end{array}$ \\
\hline$\Pi_{1}$ & & 0.46 & & & 0.26 & & & 0.96 & \\
\hline$\Pi_{2}$ & & 0.54 & & & 0.74 & & & 0.04 & \\
\hline Log Likelihood value & & $-34,454.38$ & & & $-1,536.23$ & & & $-1,975.42$ & \\
\hline Number of observations & & 27,508 & & & 681 & & & 1,282 & \\
\hline
\end{tabular}

Note: Standard errors appear in parentheses. 
Table 8. Simulation of poverty persistence for men by age, education, unemployment rate, marital status and number of children.

\begin{tabular}{|c|c|c|c|c|c|c|c|c|c|c|c|c|}
\hline \multirow[b]{2}{*}{ Variable } & \multicolumn{4}{|c|}{ Native $^{4}$} & \multicolumn{4}{|c|}{ Refugee $^{5}$} & \multicolumn{4}{|c|}{ Non-refugee } \\
\hline & $\begin{array}{l}\text { Years } \\
\text { poor }\end{array}$ & $\begin{array}{c}5+\text { years } \\
\text { poor }\end{array}$ & $\begin{array}{c}\text { Years } \\
\text { non-poor }\end{array}$ & $\begin{array}{l}<5 \text { years } \\
\text { non-poor }\end{array}$ & $\begin{array}{l}\text { Years } \\
\text { poor }\end{array}$ & $\begin{array}{c}5+\text { years } \\
\text { poor }\end{array}$ & $\begin{array}{c}\text { Years } \\
\text { non-poor }\end{array}$ & $\begin{array}{l}<5 \text { years } \\
\text { non-poor }\end{array}$ & $\begin{array}{l}\text { Years } \\
\text { poor }\end{array}$ & $\begin{array}{c}5+\text { years } \\
\text { poor }\end{array}$ & $\begin{array}{c}\text { Years } \\
\text { non-poor }\end{array}$ & $\begin{array}{l}<5 \text { years } \\
\text { non-poor }\end{array}$ \\
\hline \multicolumn{13}{|l|}{ Panel A: } \\
\hline Age $=25$ & 3.8 & $25.6 \%$ & 9.8 & $1.2 \%$ & 3.6 & $18.6 \%$ & 8.9 & $3.2 \%$ & 4.8 & $28.1 \%$ & 9.0 & $4.8 \%$ \\
\hline High School & 3.3 & $18.4 \%$ & 9.8 & $0.7 \%$ & 3.5 & $17.0 \%$ & 9.0 & $2.8 \%$ & 4.6 & $34.4 \%$ & 9.0 & $4.4 \%$ \\
\hline University & 2.9 & $14.3 \%$ & 9.9 & $0.3 \%$ & 2.8 & $8.7 \%$ & 9.4 & $1.1 \%$ & 4.6 & $35.3 \%$ & 9.3 & $3.2 \%$ \\
\hline $\begin{array}{l}\text { Unemployment } \\
\text { rate }=10 \%\end{array}$ & 4.8 & $40.5 \%$ & 9.5 & $3.1 \%$ & 5.0 & $40.5 \%$ & 7.9 & $11.4 \%$ & 5.2 & $42.5 \%$ & 8.4 & $8.6 \%$ \\
\hline $\begin{array}{l}\text { Single with two } \\
\text { children }\end{array}$ & 4.2 & $28.7 \%$ & 8.8 & $5.6 \%$ & 4.6 & $32.8 \%$ & 7.4 & $11.6 \%$ & 4.5 & $32.1 \%$ & 7.9 & $9.0 \%$ \\
\hline $\begin{array}{l}\text { Married with } \\
\text { two children }\end{array}$ & 5.1 & $44.4 \%$ & 8.2 & $10.8 \%$ & 6.3 & $62.0 \%$ & 6.2 & $29.2 \%$ & 5.7 & $50.6 \%$ & 7.5 & $15.4 \%$ \\
\hline \multicolumn{13}{|l|}{ Panel B: } \\
\hline Age $=45$ & 2.7 & $11.5 \%$ & 10.0 & $0.0 \%$ & 2.4 & $5.4 \%$ & 9.6 & $0.5 \%$ & 3.9 & $26.1 \%$ & 9.6 & $1.5 \%$ \\
\hline High School & 2.4 & $7.7 \%$ & 10.0 & $0.0 \%$ & 2.3 & $5.0 \%$ & 9.7 & $0.4 \%$ & 3.7 & $23.0 \%$ & 9.6 & $1.3 \%$ \\
\hline University & 2.2 & $5.8 \%$ & 10.0 & $0.0 \%$ & 1.9 & $1.9 \%$ & 9.8 & $0.1 \%$ & 3.7 & $24.5 \%$ & 9.7 & $1.0 \%$ \\
\hline $\begin{array}{l}\text { Unemployment } \\
\text { rate }=10 \%\end{array}$ & 3.4 & $20.6 \%$ & 9.9 & $0.4 \%$ & 3.3 & $15.9 \%$ & 9.2 & $2.2 \%$ & 4.1 & $28.4 \%$ & 9.3 & $2.6 \%$ \\
\hline $\begin{array}{l}\text { Single with two } \\
\text { children }\end{array}$ & 2.7 & $9.9 \%$ & 9.7 & $0.6 \%$ & 3.1 & $10.8 \%$ & 8.8 & $2.1 \%$ & 3.5 & $18.3 \%$ & 9.0 & $2.6 \%$ \\
\hline $\begin{array}{l}\text { Married with } \\
\text { two children }\end{array}$ & 3.3 & $18.5 \%$ & 9.6 & $1.4 \%$ & 4.4 & $30.4 \%$ & 8.1 & $8.0 \%$ & 4.5 & $33.6 \%$ & 8.8 & $5.3 \%$ \\
\hline
\end{tabular}

\footnotetext{
${ }^{4}$ The base category is a man who has compulsory school level, lives in an urban area with 5 percent unemployment rate, is single and has no children.

${ }^{5}$ For refugees and non-refugees we assume that they arrived to Sweden 15 years ago, between 1976 and 1980.
} 
Table 9. Simulation of poverty persistence for women by age, education, unemployment rate, marital status and number of children.

\begin{tabular}{|c|c|c|c|c|c|c|c|c|c|c|c|c|}
\hline \multirow[b]{2}{*}{ Variable } & \multicolumn{4}{|c|}{ Native $^{6}$} & \multicolumn{4}{|c|}{ Refugee $^{\prime}$} & \multicolumn{4}{|c|}{ Non-refugee } \\
\hline & $\begin{array}{l}\text { Years } \\
\text { poor }\end{array}$ & $\begin{array}{c}5+\text { years } \\
\text { poor }\end{array}$ & $\begin{array}{c}\text { Years } \\
\text { non-poor }\end{array}$ & $\begin{array}{l}<5 \text { years } \\
\text { non-poor }\end{array}$ & $\begin{array}{l}\text { Years } \\
\text { poor }\end{array}$ & $\begin{array}{c}5+\text { years } \\
\text { poor }\end{array}$ & $\begin{array}{c}\text { Years } \\
\text { non-poor }\end{array}$ & $\begin{array}{l}<5 \text { years } \\
\text { non-poor }\end{array}$ & $\begin{array}{l}\text { Years } \\
\text { poor }\end{array}$ & $\begin{array}{c}5+\text { years } \\
\text { poor }\end{array}$ & $\begin{array}{c}\text { Years } \\
\text { non-poor }\end{array}$ & $\begin{array}{l}<5 \text { years } \\
\text { non-poor }\end{array}$ \\
\hline \multicolumn{13}{|l|}{ Panel A: } \\
\hline Age $=25$ & 2.8 & $11.6 \%$ & 9.9 & $0.3 \%$ & 5.2 & $42.3 \%$ & 9.1 & $5.4 \%$ & 3.5 & $22.0 \%$ & 9.8 & $0.1 \%$ \\
\hline High School & 2.4 & $6.9 \%$ & 9.9 & $0.2 \%$ & 3.8 & $24.6 \%$ & 9.7 & $1.2 \%$ & 3.0 & $15.9 \%$ & 9.9 & $0.2 \%$ \\
\hline University & 2.1 & $4.7 \%$ & 9.9 & $0.1 \%$ & 3.2 & $16.9 \%$ & 9.6 & $1.0 \%$ & 2.8 & $13.5 \%$ & 9.9 & $0.1 \%$ \\
\hline $\begin{array}{l}\text { Unemployment } \\
\text { rate }=10 \%\end{array}$ & 3.5 & $21.4 \%$ & 9.7 & $1.3 \%$ & 5.4 & $45.4 \%$ & 8.8 & $7.3 \%$ & 3.7 & $23.2 \%$ & 9.6 & $1.5 \%$ \\
\hline $\begin{array}{l}\text { Single with two } \\
\text { children }\end{array}$ & 5.6 & $52.5 \%$ & 7.8 & $15.1 \%$ & 5.6 & $48.2 \%$ & 7.5 & $15.2 \%$ & 5.4 & $45.7 \%$ & 7.7 & $13.5 \%$ \\
\hline $\begin{array}{l}\text { Married with } \\
\text { two children }\end{array}$ & 6.0 & $58.6 \%$ & 7.8 & $16.9 \%$ & 6.7 & $68.8 \%$ & 5.6 & $36.0 \%$ & 5.4 & $46.5 \%$ & 7.9 & $12.6 \%$ \\
\hline \multicolumn{13}{|l|}{ Panel B: } \\
\hline Age $=45$ & 1.7 & $1.5 \%$ & 10.0 & $0.0 \%$ & 3.5 & $21.5 \%$ & 9.8 & $0.6 \%$ & 2.1 & $5.5 \%$ & 9.9 & $0.1 \%$ \\
\hline High School & 1.5 & $0.7 \%$ & 10.0 & $0.0 \%$ & 2.5 & $10.7 \%$ & 10.0 & $0.1 \%$ & 1.8 & $3.4 \%$ & 10.0 & $0.0 \%$ \\
\hline University & 1.4 & $0.5 \%$ & 10.0 & $0.0 \%$ & 2.1 & $6.0 \%$ & 10.0 & $0.0 \%$ & 1.7 & $2.7 \%$ & 10.0 & $0.0 \%$ \\
\hline $\begin{array}{l}\text { Unemployment } \\
\text { rate }=10 \%\end{array}$ & 2.1 & $4.2 \%$ & 10.0 & $0.0 \%$ & 3.6 & $23.0 \%$ & 9.8 & $0.8 \%$ & 2.2 & $6.2 \%$ & 9.9 & $0.2 \%$ \\
\hline $\begin{array}{l}\text { Single with two } \\
\text { children }\end{array}$ & 3.0 & $13.8 \%$ & 9.6 & $1.1 \%$ & 3.5 & $19.4 \%$ & 9.3 & $2.1 \%$ & 3.5 & $15.4 \%$ & 8.8 & $2.5 \%$ \\
\hline $\begin{array}{l}\text { Married with } \\
\text { two children }\end{array}$ & 3.3 & $18.6 \%$ & 9.6 & $1.4 \%$ & 4.5 & $31.6 \%$ & 8.2 & $7.5 \%$ & 3.4 & $15.5 \%$ & 8.9 & $2.4 \%$ \\
\hline
\end{tabular}

\footnotetext{
6 The base category is a woman who has compulsory school level, lives in an urban area with 5 percent unemployment rate, is single and has no children.

${ }^{7}$ For refugees and non-refugees we assume that they arrived in Sweden 15 years ago, between 1976 and 1980.
} 
Figure 1. Poverty Rates for Men 1991-2001, by Immigrant Group.

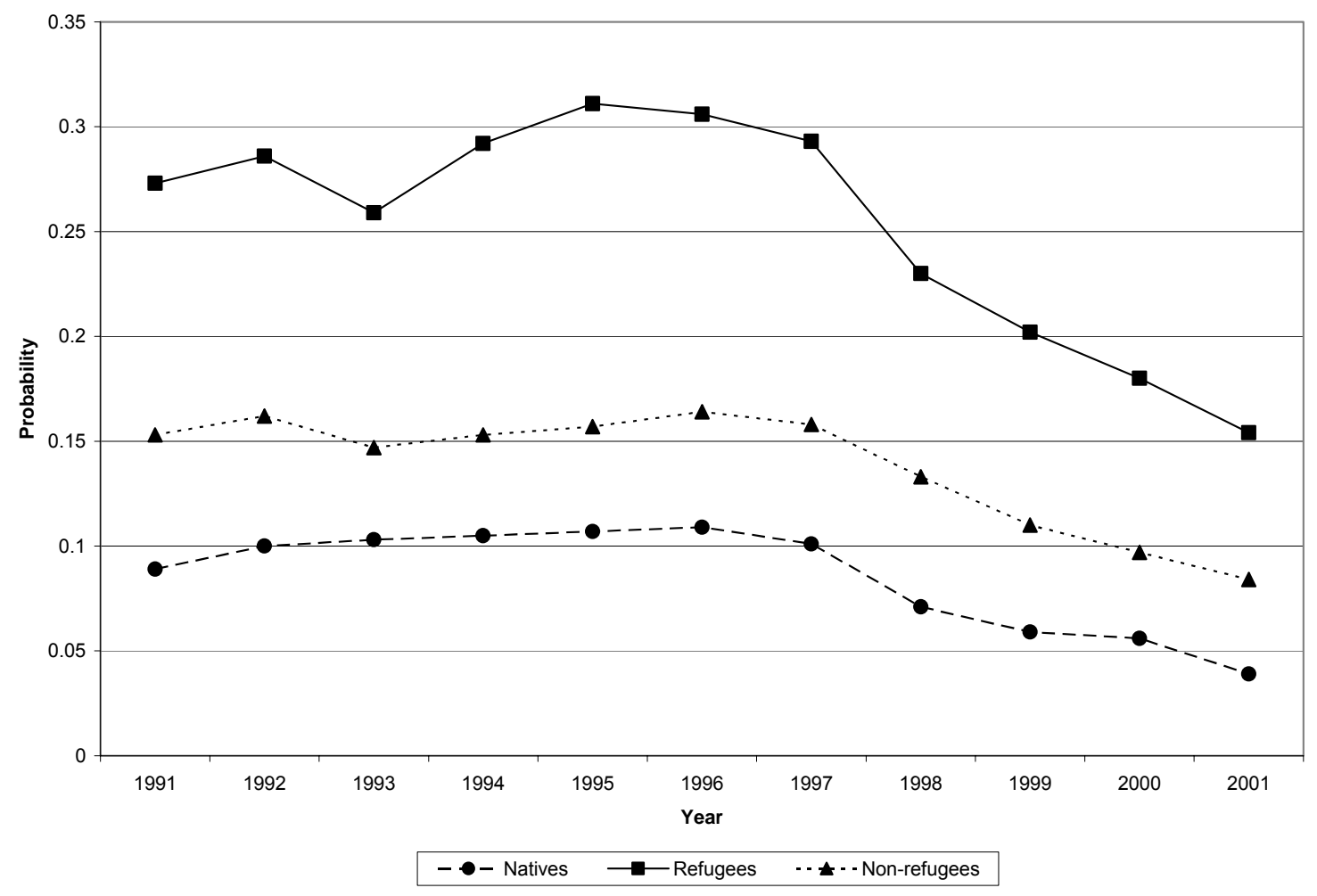


Figure 2. Poverty Rates for Women 1991-2001, by Immigrant Group.

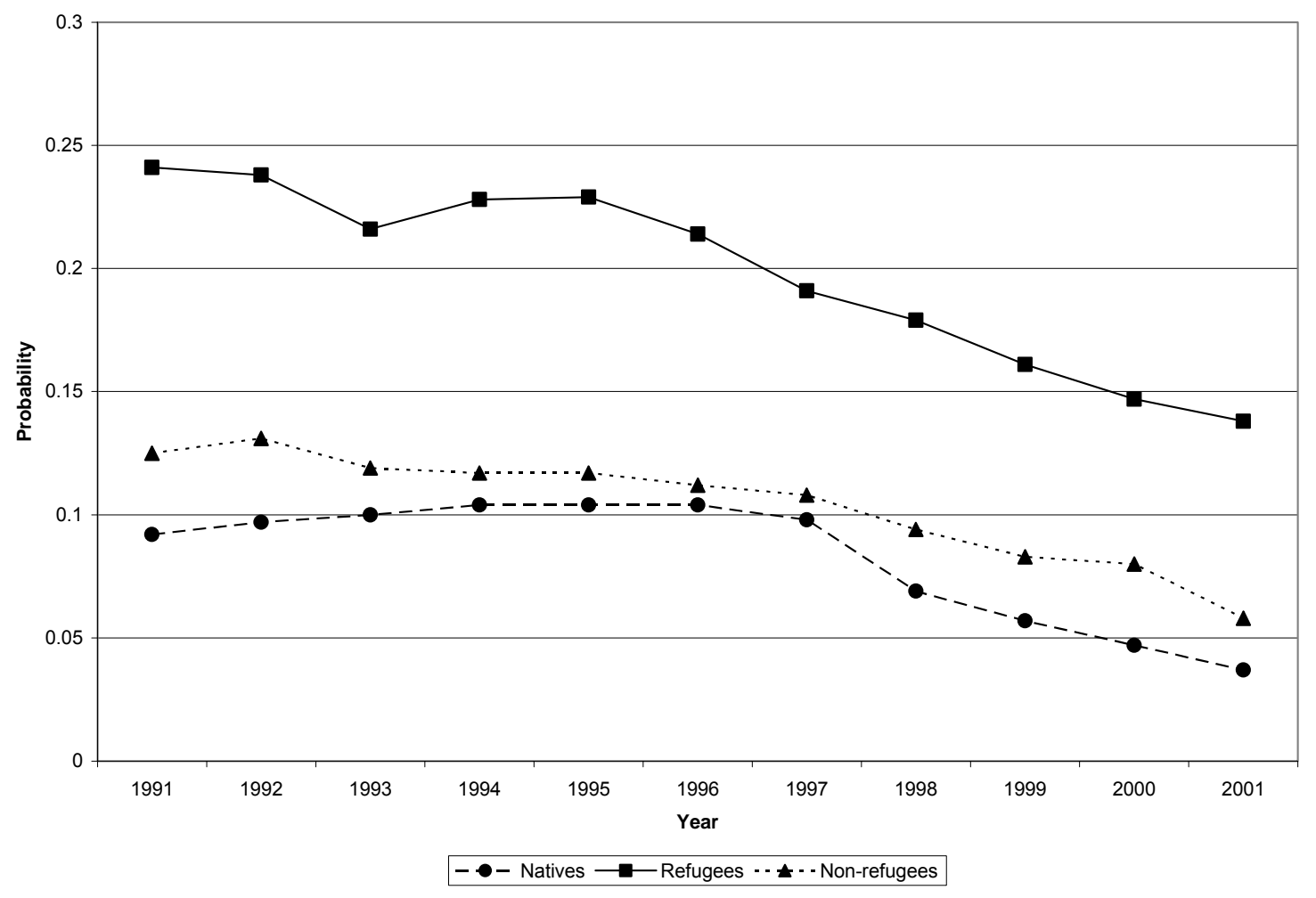


Figure 3. Transition Probabilities into Poverty for Men, by Immigrant Group.

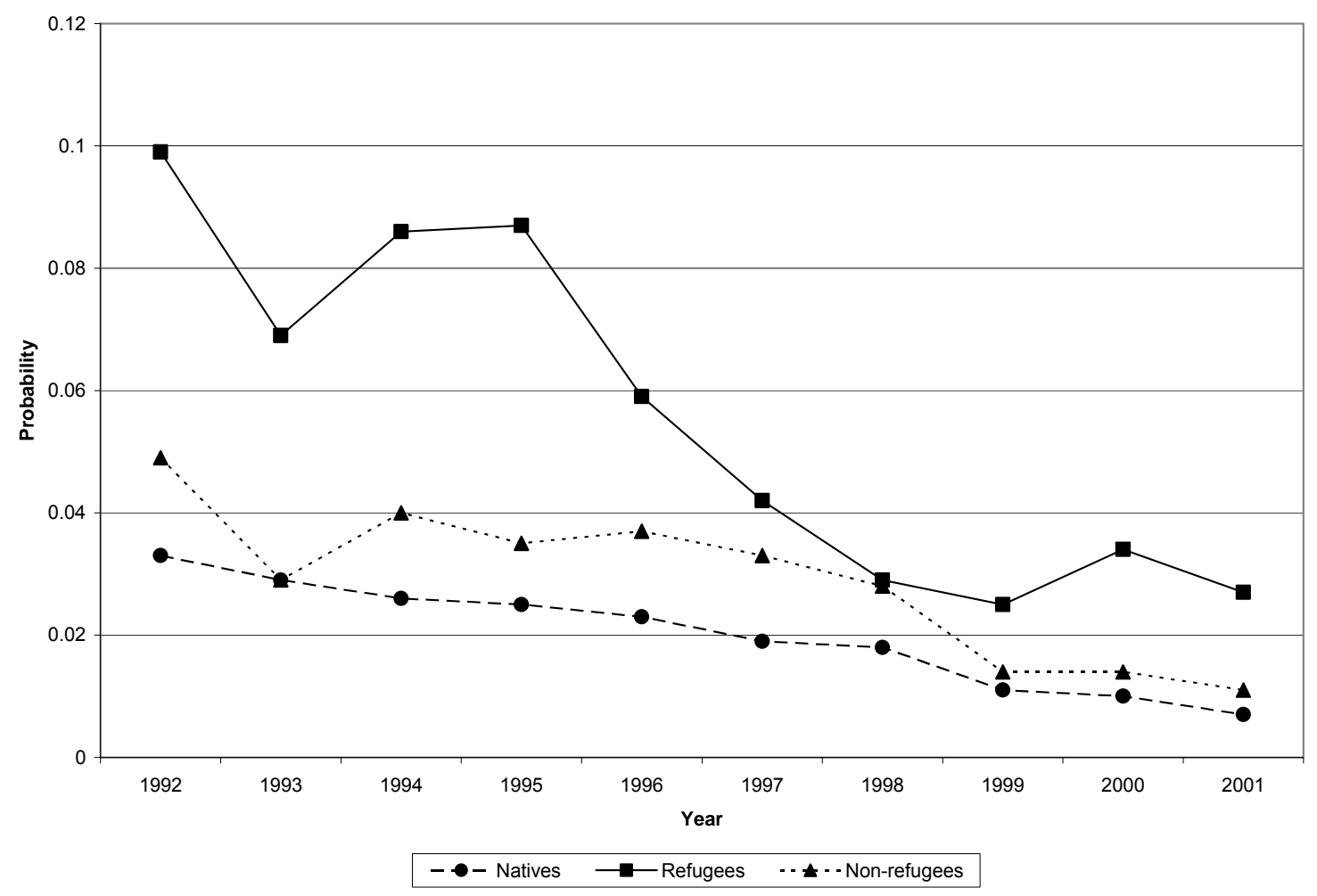


Figure 4. Transition Probabilities into Poverty for Women, by Immigrant Group.

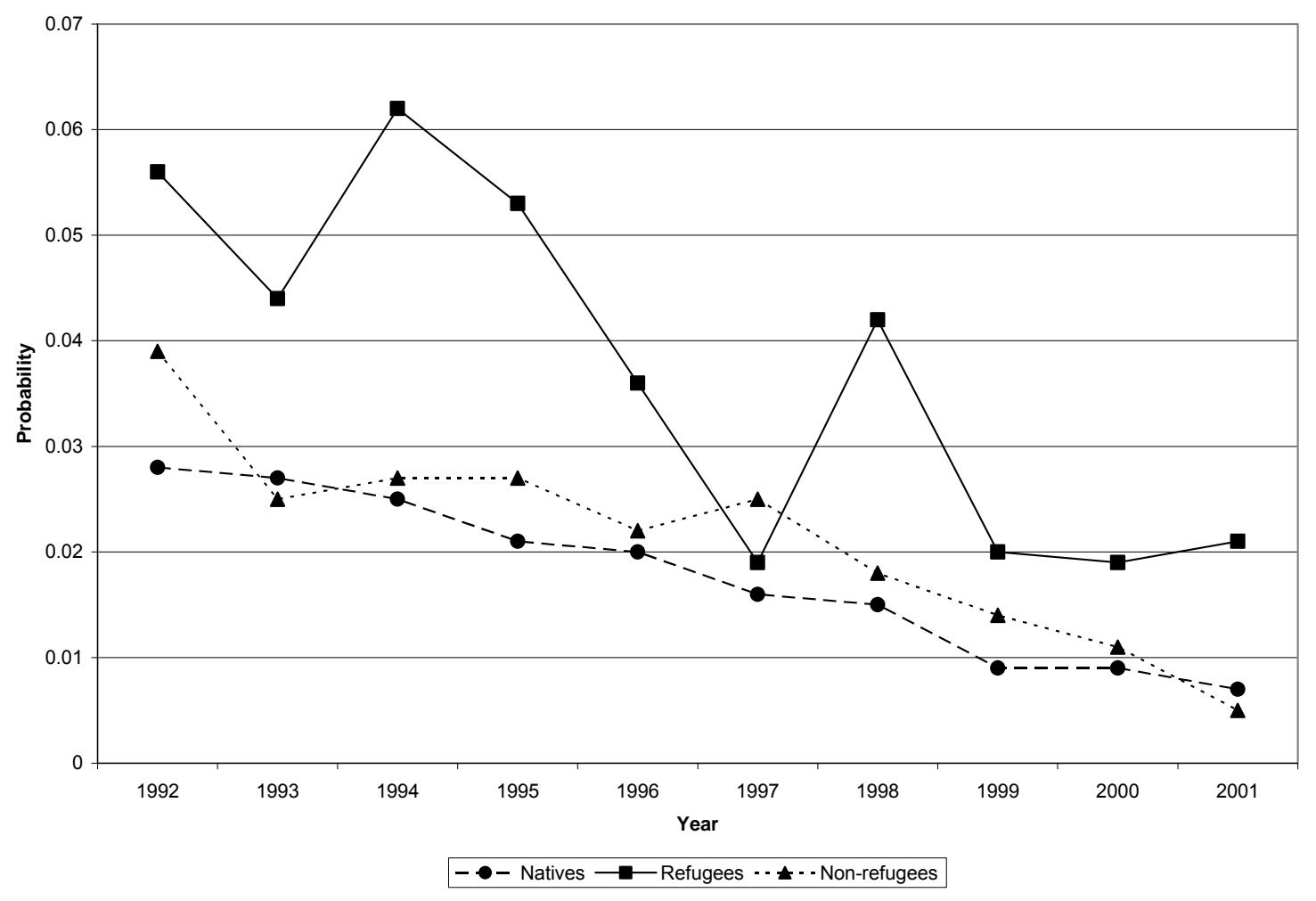


Figure 5. Transition Probabilities out of Poverty for Men, by Immigrant Group.

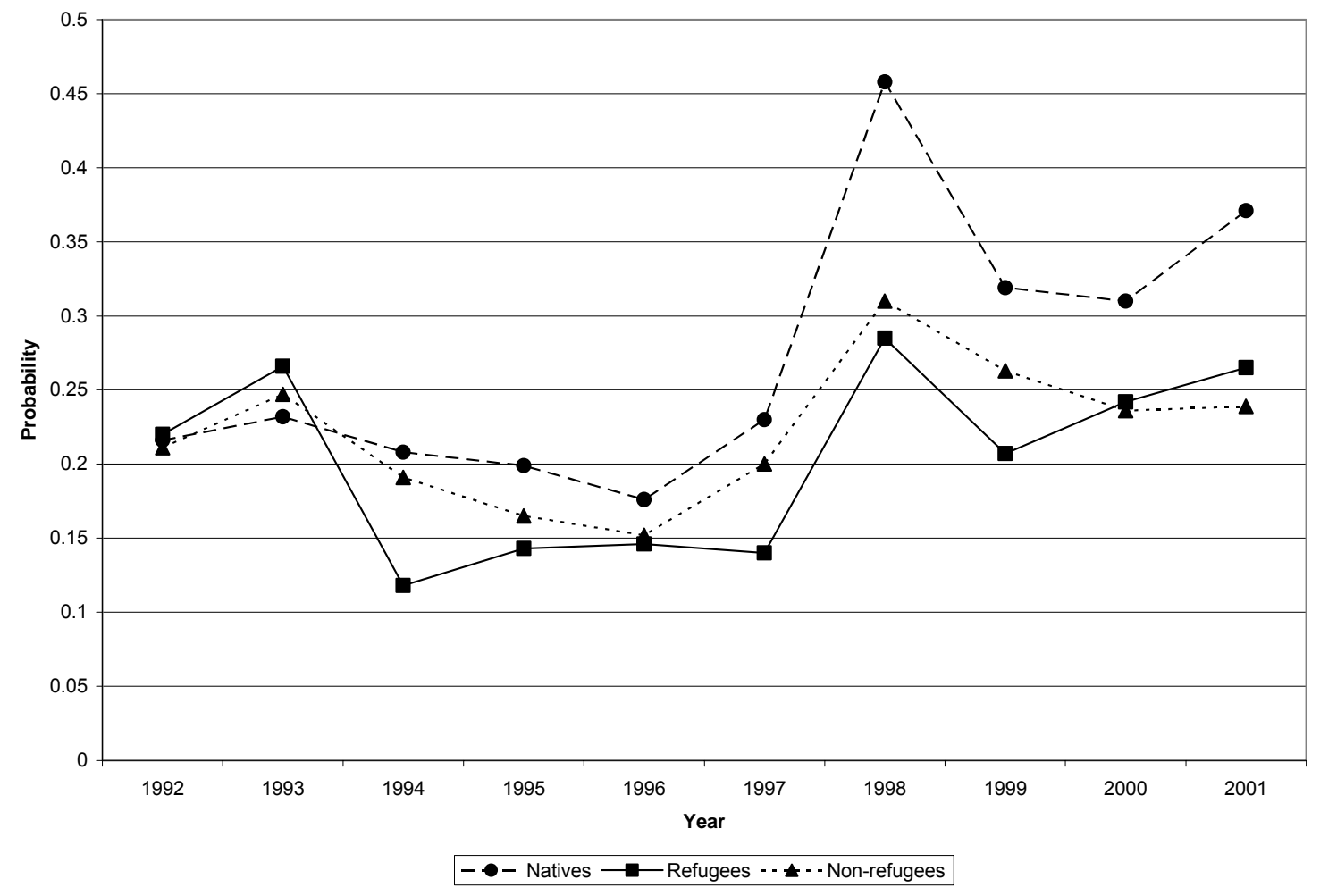


Figure 6. Transition Probabilities out of Poverty for Women, by Immigrant Group.

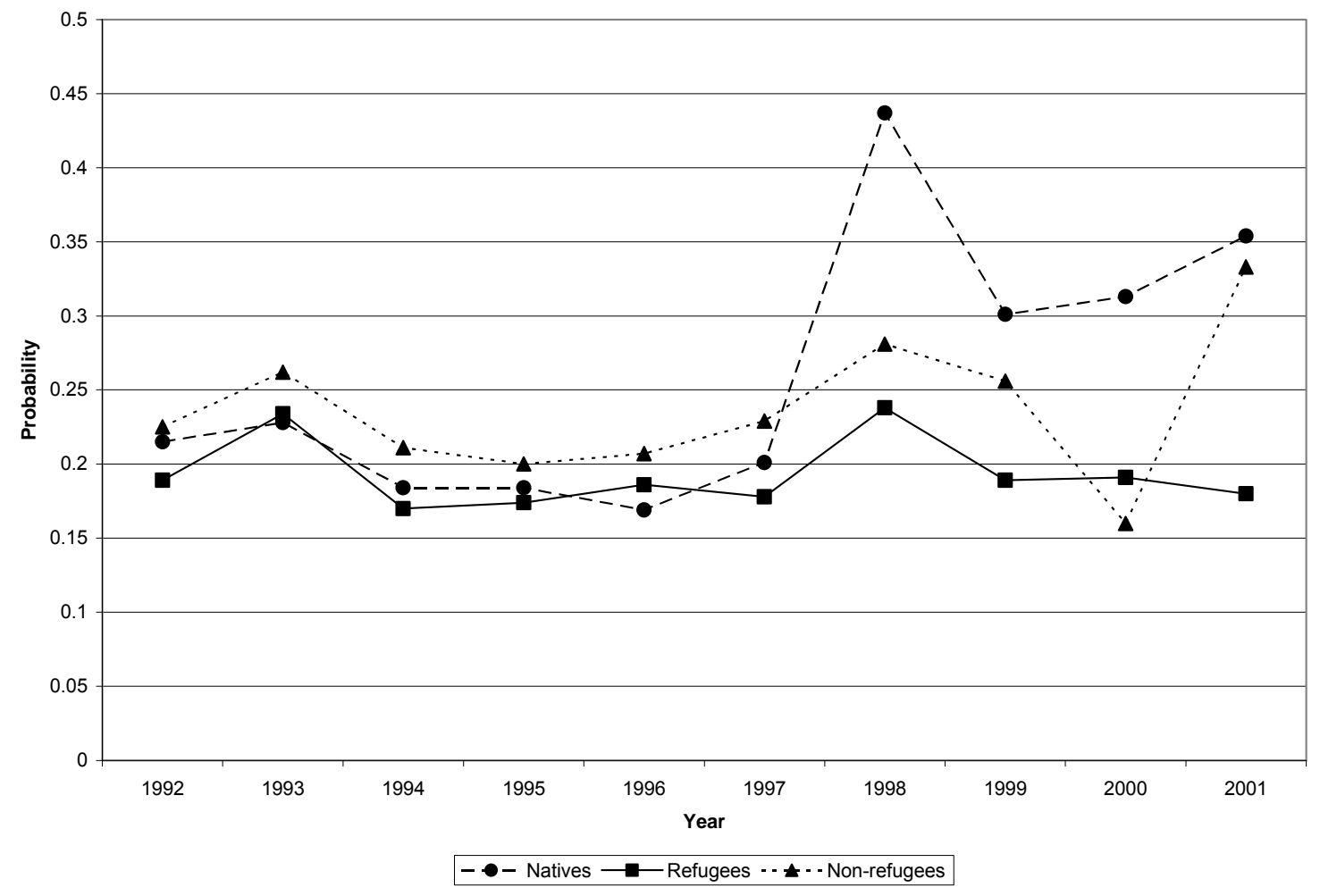




\section{Appendix}

Table 1A. Coefficients from Maximum Likelihood Estimation of Hazard Rates without Unobserved Heterogeneity.

\begin{tabular}{|c|c|c|c|c|c|c|c|c|c|}
\hline \multicolumn{10}{|c|}{ Men } \\
\hline \multirow[b]{2}{*}{ Variable } & \multicolumn{3}{|c|}{ Native } & \multicolumn{3}{|c|}{ Refugee } & \multicolumn{3}{|c|}{ Non-refugee } \\
\hline & $\begin{array}{c}\text { Initial } \\
\text { condition }\end{array}$ & $\begin{array}{c}\text { Exit } \\
\text { Poverty }\end{array}$ & $\begin{array}{c}\text { Enter } \\
\text { Poverty }\end{array}$ & $\begin{array}{c}\text { Initial } \\
\text { condition }\end{array}$ & $\begin{array}{c}\text { Exit } \\
\text { Poverty }\end{array}$ & $\begin{array}{c}\text { Enter } \\
\text { Poverty }\end{array}$ & $\begin{array}{c}\text { Initial } \\
\text { condition }\end{array}$ & $\begin{array}{c}\text { Exit } \\
\text { Poverty }\end{array}$ & $\begin{array}{c}\text { Enter } \\
\text { Poverty }\end{array}$ \\
\hline Constant & $\begin{array}{l}-2.47 \\
(0.12)\end{array}$ & $\begin{array}{c}0.33 \\
(0.08)\end{array}$ & $\begin{array}{l}-1.19 \\
(0.05)\end{array}$ & $\begin{array}{l}-1.70 \\
(0.53)\end{array}$ & $\begin{array}{c}0.03 \\
(0.30)\end{array}$ & $\begin{array}{l}-0.87 \\
(0.25)\end{array}$ & $\begin{array}{c}-2.32 \\
(0.44)\end{array}$ & $\begin{array}{c}-0.75 \\
(0.31)\end{array}$ & $\begin{array}{l}-2.02 \\
(0.23)\end{array}$ \\
\hline Single & $\begin{array}{c}0.92 \\
(0.06)\end{array}$ & $\begin{array}{l}-0.78 \\
(0.05)\end{array}$ & $\begin{array}{c}0.05 \\
(0.02)\end{array}$ & $\begin{array}{c}0.52 \\
(0.19)\end{array}$ & $\begin{array}{l}-0.48 \\
(0.13)\end{array}$ & $\begin{array}{c}0.03 \\
(0.09)\end{array}$ & $\begin{array}{c}0.88 \\
(0.17)\end{array}$ & $\begin{array}{l}-0.56 \\
(0.12)\end{array}$ & $\begin{array}{c}0.35 \\
(0.08)\end{array}$ \\
\hline High school & $\begin{array}{l}-0.21 \\
(0.03)\end{array}$ & $\begin{array}{c}0.13 \\
(0.02)\end{array}$ & $\begin{array}{l}-0.06 \\
(0.02)\end{array}$ & $\begin{array}{l}-0.03 \\
(0.13)\end{array}$ & $\begin{array}{c}0.02 \\
(0.07)\end{array}$ & $\begin{array}{l}-0.09 \\
(0.07)\end{array}$ & $\begin{array}{c}0.09 \\
(0.11)\end{array}$ & $\begin{array}{c}0.03 \\
(0.07)\end{array}$ & $\begin{array}{c}0.03 \\
(0.06)\end{array}$ \\
\hline University & $\begin{array}{l}-0.74 \\
(0.04)\end{array}$ & $\begin{array}{c}0.23 \\
(0.03)\end{array}$ & $\begin{array}{l}-0.34 \\
(0.02)\end{array}$ & $\begin{array}{l}-0.50 \\
(0.17)\end{array}$ & $\begin{array}{c}0.13 \\
(0.10)\end{array}$ & $\begin{array}{l}-0.18 \\
(0.09)\end{array}$ & $\begin{array}{l}-0.07 \\
(0.14)\end{array}$ & $\begin{array}{l}-0.03 \\
(0.10)\end{array}$ & $\begin{array}{l}-0.15 \\
(0.08)\end{array}$ \\
\hline \# Children & $\begin{array}{c}1.07 \\
(0.02)\end{array}$ & $\begin{array}{l}-0.44 \\
(0.01)\end{array}$ & $\begin{array}{c}0.44 \\
(0.01)\end{array}$ & $\begin{array}{c}0.87 \\
(0.08)\end{array}$ & $\begin{array}{l}-0.36 \\
(0.04)\end{array}$ & $\begin{array}{c}0.29 \\
(0.04)\end{array}$ & $\begin{array}{c}0.86 \\
(0.07)\end{array}$ & $\begin{array}{l}-0.19 \\
(0.03)\end{array}$ & $\begin{array}{c}0.41 \\
(0.04)\end{array}$ \\
\hline \# Children*Single & $\begin{array}{l}-0.58 \\
(0.07)\end{array}$ & $\begin{array}{c}0.51 \\
(0.04)\end{array}$ & $\begin{array}{l}-0.06 \\
(0.03)\end{array}$ & $\begin{array}{l}-0.60 \\
(0.20)\end{array}$ & $\begin{array}{c}0.43 \\
(0.09)\end{array}$ & $\begin{array}{l}-0.09 \\
(0.11)\end{array}$ & $\begin{array}{l}-0.87 \\
(0.23)\end{array}$ & $\begin{array}{c}0.40 \\
(0.11)\end{array}$ & $\begin{array}{l}-0.17 \\
(0.10)\end{array}$ \\
\hline Age & $\begin{array}{l}-1.33 \\
(0.19)\end{array}$ & $\begin{array}{l}1.29 \\
(0.14)\end{array}$ & $\begin{array}{l}-2.70 \\
(0.09)\end{array}$ & $\begin{array}{l}-0.11 \\
(0.84)\end{array}$ & $\begin{array}{c}1.23 \\
(0.51)\end{array}$ & $\begin{array}{l}-1.87 \\
(0.43)\end{array}$ & $\begin{array}{l}-0.30 \\
(0.68)\end{array}$ & $\begin{array}{c}0.46 \\
(0.50)\end{array}$ & $\begin{array}{l}-1.14 \\
(0.36)\end{array}$ \\
\hline Residing in large-sized cities & $\begin{array}{l}-0.34 \\
(0.04)\end{array}$ & $\begin{array}{c}0.10 \\
(0.02)\end{array}$ & $\begin{array}{l}-0.14 \\
(0.02)\end{array}$ & $\begin{array}{l}-0.02 \\
(0.23)\end{array}$ & $\begin{array}{l}-0.05 \\
(0.13)\end{array}$ & $\begin{array}{c}0.05 \\
(0.11)\end{array}$ & $\begin{array}{c}0.19 \\
(0.14)\end{array}$ & $\begin{array}{l}-0.07 \\
(0.09)\end{array}$ & $\begin{array}{c}0.11 \\
(0.07)\end{array}$ \\
\hline $\begin{array}{l}\text { Residing in medium-sized } \\
\text { cities }\end{array}$ & $\begin{array}{l}-0.23 \\
(0.03)\end{array}$ & $\begin{array}{l}0.09 \\
(0.02)\end{array}$ & $\begin{array}{l}-0.13 \\
(0.02)\end{array}$ & $\begin{array}{l}0.16 \\
(0.24)\end{array}$ & $\begin{array}{l}-0.12 \\
(0.14)\end{array}$ & $\begin{array}{l}-0.02 \\
(0.12)\end{array}$ & $\begin{array}{l}0.06 \\
(0.15)\end{array}$ & $\begin{array}{l}0.02 \\
(0.10)\end{array}$ & $\begin{array}{l}-0.01 \\
(0.08)\end{array}$ \\
\hline Local unemployment rate & $\begin{array}{l}0.44 \\
(0.08)\end{array}$ & $\begin{array}{l}-0.49 \\
(0.04)\end{array}$ & $\begin{array}{l}0.36 \\
(0.03)\end{array}$ & $\begin{array}{l}0.98 \\
(0.37)\end{array}$ & $\begin{array}{l}-0.54 \\
(0.15)\end{array}$ & $\begin{array}{l}0.48 \\
(0.13)\end{array}$ & $\begin{array}{c}0.42 \\
(0.27)\end{array}$ & $\begin{array}{l}0.10 \\
(0.14)\end{array}$ & $\begin{array}{c}0.48 \\
(0.11)\end{array}$ \\
\hline
\end{tabular}

Continued... 
Table 1A Continued:

\begin{tabular}{|c|c|c|c|c|c|c|c|c|c|}
\hline \multicolumn{10}{|l|}{ Durations (years) } \\
\hline 2 & - & $\begin{array}{c}-0.22 \\
(0.03)\end{array}$ & $\begin{array}{l}-0.21 \\
(0.02)\end{array}$ & - & $\begin{array}{l}-0.14 \\
(0.10)\end{array}$ & $\begin{array}{c}-0.36 \\
(0.09)\end{array}$ & - & $\begin{array}{l}-0.33 \\
(0.10)\end{array}$ & $\begin{array}{l}-0.30 \\
(0.08)\end{array}$ \\
\hline 3 & - & $\begin{array}{l}-0.26 \\
(0.03)\end{array}$ & $\begin{array}{l}-0.42 \\
(0.02)\end{array}$ & - & $\begin{array}{l}-0.24 \\
(0.12)\end{array}$ & $\begin{array}{l}-0.33 \\
(0.10)\end{array}$ & - & $\begin{array}{l}-0.47 \\
(0.11)\end{array}$ & $\begin{array}{c}-0.43 \\
(0.09)\end{array}$ \\
\hline 4 & - & $\begin{array}{l}-0.41 \\
(0.03)\end{array}$ & $\begin{array}{l}-0.42 \\
(0.02)\end{array}$ & - & $\begin{array}{l}-0.36 \\
(0.13)\end{array}$ & $\begin{array}{l}-0.45 \\
(0.11)\end{array}$ & - & $\begin{array}{l}-0.73 \\
(0.13)\end{array}$ & $\begin{array}{l}-0.51 \\
(0.10)\end{array}$ \\
\hline 5 & - & $\begin{array}{l}-0.40 \\
(0.04)\end{array}$ & $\begin{array}{l}-0.40 \\
(0.03)\end{array}$ & - & $\begin{array}{l}-0.40 \\
(0.14)\end{array}$ & $\begin{array}{l}-0.44 \\
(0.12)\end{array}$ & - & $\begin{array}{l}-0.68 \\
(0.14)\end{array}$ & $\begin{array}{c}-0.49 \\
(0.10)\end{array}$ \\
\hline 6 or more & - & $\begin{array}{l}-0.18 \\
(0.03)\end{array}$ & $\begin{array}{l}-0.51 \\
(0.02)\end{array}$ & - & $\begin{array}{c}-0.36 \\
(0.11)\end{array}$ & $\begin{array}{l}-0.71 \\
(0.10)\end{array}$ & - & $\begin{array}{l}-0.63 \\
(0.10)\end{array}$ & $\begin{array}{l}-0.61 \\
(0.08)\end{array}$ \\
\hline Years since arrival & - & - & - & $\begin{array}{l}-0.13 \\
(0.07)\end{array}$ & $\begin{array}{l}-0.00 \\
(0.03)\end{array}$ & $\begin{array}{c}0.00 \\
(0.02)\end{array}$ & $\begin{array}{c}0.01 \\
(0.03)\end{array}$ & $\begin{array}{c}0.06 \\
(0.03)\end{array}$ & $\begin{array}{c}0.06 \\
(0.02)\end{array}$ \\
\hline Years since arrival ${ }^{2} / 100$ & - & - & - & $\begin{array}{c}0.35 \\
(0.28)\end{array}$ & $\begin{array}{c}0.10 \\
(0.09)\end{array}$ & $\begin{array}{l}-0.04 \\
(0.08)\end{array}$ & $\begin{array}{l}-0.10 \\
(0.20)\end{array}$ & $\begin{array}{l}-0.02 \\
(0.07)\end{array}$ & $\begin{array}{c}-0.12 \\
(0.06)\end{array}$ \\
\hline Arrived in 1968 & - & - & - & $\begin{array}{l}-0.04 \\
(0.56)\end{array}$ & $\begin{array}{l}-0.34 \\
(0.26)\end{array}$ & $\begin{array}{l}-0.27 \\
(0.20)\end{array}$ & $\begin{array}{l}-0.30 \\
(0.41)\end{array}$ & $\begin{array}{l}-0.58 \\
(0.18)\end{array}$ & $\begin{array}{c}-0.71 \\
(0.16)\end{array}$ \\
\hline Arrived in 1976 & - & - & - & $\begin{array}{c}0.28 \\
(0.39)\end{array}$ & $\begin{array}{l}-0.23 \\
(0.15)\end{array}$ & $\begin{array}{l}-0.10 \\
(0.13)\end{array}$ & $\begin{array}{l}-0.35 \\
(0.35)\end{array}$ & $\begin{array}{l}-0.44 \\
(0.15)\end{array}$ & $\begin{array}{l}-0.47 \\
(0.13)\end{array}$ \\
\hline Arrived in 1981 & - & - & - & $\begin{array}{c}0.06 \\
(0.25)\end{array}$ & $\begin{array}{c}-0.03 \\
(0.11)\end{array}$ & $\begin{array}{c}0.04 \\
(0.09)\end{array}$ & $\begin{array}{l}-0.29 \\
(0.26)\end{array}$ & $\begin{array}{l}-0.28 \\
(0.13)\end{array}$ & $\begin{array}{c}-0.26 \\
(0.11)\end{array}$ \\
\hline$\Theta_{1}$ & - & - & - & - & - & - & - & - & - \\
\hline$\Theta_{2}$ & - & - & - & - & - & - & - & - & - \\
\hline$\Pi_{1}$ & - & - & - & - & - & - & - & - & - \\
\hline$\Pi_{2}$ & - & - & - & - & - & - & - & - & - \\
\hline Log Likelihood value & & $-40,425.63$ & & & $-2,393.60$ & & & $-2,852.59$ & \\
\hline Number of observations & & 28,989 & & & 816 & & & 1,426 & \\
\hline
\end{tabular}

Note: Standard errors appear in parentheses. 
Table 2A. Coefficients from Maximum Likelihood Estimation of Hazard Rates without Unobserved Heterogeneity.

\begin{tabular}{|c|c|c|c|c|c|c|c|c|c|}
\hline \multicolumn{10}{|c|}{ Women } \\
\hline & \multicolumn{3}{|c|}{ Native } & \multicolumn{3}{|c|}{ Refugee } & \multicolumn{3}{|c|}{ Non-refugee } \\
\hline Variable & $\begin{array}{c}\text { Initial } \\
\text { condition }\end{array}$ & $\begin{array}{c}\text { Exit } \\
\text { Poverty }\end{array}$ & $\begin{array}{l}\text { Enter } \\
\text { Poverty }\end{array}$ & $\begin{array}{c}\text { Initial } \\
\text { condition }\end{array}$ & $\begin{array}{c}\text { Exit } \\
\text { Poverty }\end{array}$ & $\begin{array}{c}\text { Enter } \\
\text { Poverty }\end{array}$ & $\begin{array}{c}\text { Initial } \\
\text { condition }\end{array}$ & $\begin{array}{c}\text { Exit } \\
\text { Poverty }\end{array}$ & $\begin{array}{l}\text { Enter } \\
\text { Poverty }\end{array}$ \\
\hline Constant & $\begin{array}{l}-2.00 \\
(0.12)\end{array}$ & $\begin{array}{l}-0.35 \\
(0.09)\end{array}$ & $\begin{array}{l}-1.07 \\
(0.06)\end{array}$ & $\begin{array}{l}-0.62 \\
(0.57)\end{array}$ & $\begin{array}{l}-0.77 \\
(0.37)\end{array}$ & $\begin{array}{l}-0.83 \\
(0.32)\end{array}$ & $\begin{array}{l}-1.31 \\
(0.50)\end{array}$ & $\begin{array}{l}-1.16 \\
(0.36)\end{array}$ & $\begin{array}{l}-1.60 \\
(0.29)\end{array}$ \\
\hline Single & $\begin{array}{c}0.55 \\
(0.06)\end{array}$ & $\begin{array}{l}-0.25 \\
(0.06)\end{array}$ & $\begin{array}{l}-0.18 \\
(0.03)\end{array}$ & $\begin{array}{l}-0.12 \\
(0.24)\end{array}$ & $\begin{array}{l}-1.30 \\
(0.20)\end{array}$ & $\begin{array}{l}-0.14 \\
(0.13)\end{array}$ & $\begin{array}{c}0.67 \\
(0.19)\end{array}$ & $\begin{array}{l}-0.75 \\
(0.16)\end{array}$ & $\begin{array}{l}-0.20 \\
(0.12)\end{array}$ \\
\hline High school & $\begin{array}{l}-0.21 \\
(0.04)\end{array}$ & $\begin{array}{c}0.17 \\
(0.03)\end{array}$ & $\begin{array}{l}-0.11 \\
(0.02)\end{array}$ & $\begin{array}{l}-0.15 \\
(0.15)\end{array}$ & $\begin{array}{c}0.23 \\
(0.10)\end{array}$ & $\begin{array}{l}-0.29 \\
(0.09)\end{array}$ & $\begin{array}{l}-0.06 \\
(0.12)\end{array}$ & $\begin{array}{c}0.08 \\
(0.09)\end{array}$ & $\begin{array}{l}-0.16 \\
(0.07)\end{array}$ \\
\hline University & $\begin{array}{l}-0.62 \\
(0.04)\end{array}$ & $\begin{array}{c}0.26 \\
(0.03)\end{array}$ & $\begin{array}{l}-0.26 \\
(0.02)\end{array}$ & $\begin{array}{l}-0.23 \\
(0.18)\end{array}$ & $\begin{array}{c}0.48 \\
(0.13)\end{array}$ & $\begin{array}{l}-0.25 \\
(0.10)\end{array}$ & $\begin{array}{l}-0.15 \\
(0.14)\end{array}$ & $\begin{array}{c}0.10 \\
(0.11)\end{array}$ & $\begin{array}{l}-0.29 \\
(0.09)\end{array}$ \\
\hline \# Children & $\begin{array}{c}0.99 \\
(0.02)\end{array}$ & $\begin{array}{l}-0.43 \\
(0.01)\end{array}$ & $\begin{array}{c}0.43 \\
(0.01)\end{array}$ & $\begin{array}{c}0.72 \\
(0.08)\end{array}$ & $\begin{array}{l}-0.51 \\
(0.06)\end{array}$ & $\begin{array}{c}0.33 \\
(0.05)\end{array}$ & $\begin{array}{c}0.72 \\
(0.07)\end{array}$ & $\begin{array}{l}-0.14 \\
(0.04)\end{array}$ & $\begin{array}{c}0.39 \\
(0.04)\end{array}$ \\
\hline \# Children*Single & $\begin{array}{l}-0.25 \\
(0.04)\end{array}$ & $\begin{array}{c}0.19 \\
(0.03)\end{array}$ & $\begin{array}{c}0.12 \\
(0.02)\end{array}$ & $\begin{array}{l}-0.02 \\
(0.14)\end{array}$ & $\begin{array}{c}0.64 \\
(0.09)\end{array}$ & $\begin{array}{l}-0.12 \\
(0.10)\end{array}$ & $\begin{array}{l}-0.31 \\
(0.11)\end{array}$ & $\begin{array}{c}0.36 \\
(0.07)\end{array}$ & $\begin{array}{c}0.11 \\
(0.08)\end{array}$ \\
\hline Age & $\begin{array}{l}-1.32 \\
(0.21)\end{array}$ & $\begin{array}{c}2.34 \\
(0.16)\end{array}$ & $\begin{array}{l}-3.03 \\
(0.10)\end{array}$ & $\begin{array}{l}-1.32 \\
(0.98)\end{array}$ & $\begin{array}{l}1.36 \\
(0.63)\end{array}$ & $\begin{array}{l}-2.75 \\
(0.54)\end{array}$ & $\begin{array}{l}-0.51 \\
(0.82)\end{array}$ & $\begin{array}{c}1.58 \\
(0.61)\end{array}$ & $\begin{array}{l}-0.80 \\
(0.50)\end{array}$ \\
\hline Residing in large-sized cities & $\begin{array}{l}-0.44 \\
(0.04)\end{array}$ & $\begin{array}{c}0.12 \\
(0.03)\end{array}$ & $\begin{array}{l}-0.15 \\
(0.02)\end{array}$ & $\begin{array}{c}0.60 \\
(0.23)\end{array}$ & $\begin{array}{l}-0.05 \\
(0.15)\end{array}$ & $\begin{array}{c}0.28 \\
(0.13)\end{array}$ & $\begin{array}{l}-0.26 \\
(0.14)\end{array}$ & $\begin{array}{l}-0.01 \\
(0.10)\end{array}$ & $\begin{array}{l}-0.03 \\
(0.09)\end{array}$ \\
\hline $\begin{array}{l}\text { Residing in medium-sized } \\
\text { cities }\end{array}$ & $\begin{array}{l}-0.24 \\
(0.03)\end{array}$ & $\begin{array}{l}0.05 \\
(0.02)\end{array}$ & $\begin{array}{l}-0.10 \\
(0.02)\end{array}$ & $\begin{array}{c}0.51 \\
(0.24)\end{array}$ & $\begin{array}{l}-0.09 \\
(0.16)\end{array}$ & $\begin{array}{c}0.11 \\
(0.14)\end{array}$ & $\begin{array}{l}-0.26 \\
(0.15)\end{array}$ & $\begin{array}{l}0.04 \\
(0.11)\end{array}$ & $\begin{array}{l}-0.06 \\
(0.09)\end{array}$ \\
\hline Local unemployment rate & $\begin{array}{l}0.16 \\
(0.10)\end{array}$ & $\begin{array}{l}-0.31 \\
(0.05)\end{array}$ & $\begin{array}{l}0.48 \\
(0.04)\end{array}$ & $\begin{array}{l}0.16 \\
(0.39)\end{array}$ & $\begin{array}{l}-0.03 \\
(0.22)\end{array}$ & $\begin{array}{l}0.28 \\
(0.22)\end{array}$ & $\begin{array}{l}0.67 \\
(0.34)\end{array}$ & $\begin{array}{l}0.07 \\
(0.22)\end{array}$ & $\begin{array}{c}0.55 \\
(0.17)\end{array}$ \\
\hline \multicolumn{10}{|l|}{ Durations (years) } \\
\hline 2 & - & $\begin{array}{l}-0.28 \\
(0.03)\end{array}$ & $\begin{array}{l}-0.18 \\
(0.02)\end{array}$ & - & $\begin{array}{l}-0.26 \\
(0.13)\end{array}$ & $\begin{array}{l}-0.27 \\
(0.11)\end{array}$ & - & $\begin{array}{l}-0.43 \\
(0.11)\end{array}$ & $\begin{array}{l}-0.34 \\
(0.10)\end{array}$ \\
\hline 3 & - & $\begin{array}{l}-0.31 \\
(0.03)\end{array}$ & $\begin{array}{l}-0.38 \\
(0.02)\end{array}$ & - & $\begin{array}{l}-0.54 \\
(0.15)\end{array}$ & $\begin{array}{l}-0.51 \\
(0.13)\end{array}$ & - & $\begin{array}{l}-0.51 \\
(0.13)\end{array}$ & $\begin{array}{l}-0.57 \\
(0.11)\end{array}$ \\
\hline
\end{tabular}

\section{Continued...}




\section{Table 2A Continued:}

\begin{tabular}{|c|c|c|c|c|c|c|c|c|c|}
\hline 4 & - & $\begin{array}{c}-0.47 \\
(0.04)\end{array}$ & $\begin{array}{c}-0.47 \\
(0.03)\end{array}$ & - & $\begin{array}{c}-0.61 \\
(0.17)\end{array}$ & $\begin{array}{c}-0.39 \\
(0.13)\end{array}$ & - & $\begin{array}{l}-0.67 \\
(0.15)\end{array}$ & $\begin{array}{l}-0.45 \\
(0.11)\end{array}$ \\
\hline 5 & - & $\begin{array}{l}-0.46 \\
(0.04)\end{array}$ & $\begin{array}{l}-0.46 \\
(0.03)\end{array}$ & - & $\begin{array}{l}-0.56 \\
(0.18)\end{array}$ & $\begin{array}{l}-0.55 \\
(0.15)\end{array}$ & - & $\begin{array}{l}-0.60 \\
(0.16)\end{array}$ & $\begin{array}{l}-0.60 \\
(0.13)\end{array}$ \\
\hline 6 or more & - & $\begin{array}{l}-0.15 \\
(0.03)\end{array}$ & $\begin{array}{l}-0.57 \\
(0.02)\end{array}$ & - & $\begin{array}{l}-0.58 \\
(0.14)\end{array}$ & $\begin{array}{l}-0.61 \\
(0.12)\end{array}$ & - & $\begin{array}{l}-0.88 \\
(0.13)\end{array}$ & $\begin{array}{l}-0.77 \\
(0.11)\end{array}$ \\
\hline Years since arrival & - & - & - & $\begin{array}{c}-0.19 \\
(0.08)\end{array}$ & $\begin{array}{c}0.11 \\
(0.04)\end{array}$ & $\begin{array}{c}0.02 \\
(0.03)\end{array}$ & $\begin{array}{l}-0.17 \\
(0.08)\end{array}$ & $\begin{array}{c}0.07 \\
(0.03)\end{array}$ & $\begin{array}{c}0.00 \\
(0.03)\end{array}$ \\
\hline Years since arrival ${ }^{2} / 100$ & - & - & - & $\begin{array}{c}0.86 \\
(0.36)\end{array}$ & $\begin{array}{l}-0.22 \\
(0.12)\end{array}$ & $\begin{array}{l}-0.00 \\
(0.10)\end{array}$ & $\begin{array}{c}0.44 \\
(0.25)\end{array}$ & $\begin{array}{l}-0.04 \\
(0.08)\end{array}$ & $\begin{array}{c}0.02 \\
(0.07)\end{array}$ \\
\hline Arrived in 1968 & - & - & - & $\begin{array}{l}-1.27 \\
(0.72)\end{array}$ & $\begin{array}{l}-0.62 \\
(0.33)\end{array}$ & $\begin{array}{l}-0.48 \\
(0.24)\end{array}$ & $\begin{array}{c}0.65 \\
(0.65)\end{array}$ & $\begin{array}{l}-0.76 \\
(0.25)\end{array}$ & $\begin{array}{c}-0.54 \\
(0.23)\end{array}$ \\
\hline Arrived in 1976 & - & - & - & $\begin{array}{l}-0.24 \\
(0.44)\end{array}$ & $\begin{array}{l}-0.33 \\
(0.19)\end{array}$ & $\begin{array}{l}-0.30 \\
(0.16)\end{array}$ & $\begin{array}{c}0.57 \\
(0.54)\end{array}$ & $\begin{array}{l}-0.46 \\
(0.19)\end{array}$ & $\begin{array}{l}-0.33 \\
(0.18)\end{array}$ \\
\hline Arrived in 1981 & - & - & - & $\begin{array}{l}-0.42 \\
(0.29)\end{array}$ & $\begin{array}{l}-0.16 \\
(0.14)\end{array}$ & $\begin{array}{l}-0.17 \\
(0.11)\end{array}$ & $\begin{array}{c}0.45 \\
(0.37)\end{array}$ & $\begin{array}{l}-0.64 \\
(0.16)\end{array}$ & $\begin{array}{c}0.08 \\
(0.13)\end{array}$ \\
\hline$\Theta_{1}$ & - & - & - & - & - & - & - & - & - \\
\hline$\Theta_{2}$ & - & - & - & - & - & - & - & - & - \\
\hline$\Pi_{1}$ & - & - & - & - & - & - & - & - & - \\
\hline$\Pi_{2}$ & - & - & - & - & - & - & - & - & - \\
\hline Log Likelihood value & & $-34,690.07$ & & & $-1,549.18$ & & & $-2,007.69$ & \\
\hline Number of individuals & & 27,508 & & & 681 & & & 1,282 & \\
\hline
\end{tabular}

Note: Standard errors appear in parentheses. 
Table 3A. Simulation of poverty persistence for refugees by age, education, unemployment rate, marital status and number of children. ${ }^{8}$

\begin{tabular}{|c|c|c|c|c|c|c|c|c|}
\hline \multirow[b]{2}{*}{ Variable } & \multicolumn{4}{|c|}{ Men } & \multicolumn{4}{|c|}{ Women } \\
\hline & $\begin{array}{l}\text { Years } \\
\text { poor }\end{array}$ & $\begin{array}{c}5+\text { years } \\
\text { poor }\end{array}$ & $\begin{array}{c}\text { Years } \\
\text { non-poor }\end{array}$ & $\begin{array}{l}<5 \text { years } \\
\text { non-poor } \\
\end{array}$ & $\begin{array}{l}\text { Years } \\
\text { poor }\end{array}$ & $\begin{array}{c}5+\text { years } \\
\text { poor }\end{array}$ & $\begin{array}{c}\text { Years } \\
\text { non-poor }\end{array}$ & $\begin{array}{l}<5 \text { years } \\
\text { non-poor }\end{array}$ \\
\hline \multicolumn{9}{|l|}{ Panel A: } \\
\hline Age $=25$ & 3.8 & $21.6 \%$ & 8.8 & $4.0 \%$ & 5.0 & $40.5 \%$ & 9.2 & $4.2 \%$ \\
\hline High School & 3.6 & $19.1 \%$ & 9.0 & $3.2 \%$ & 3.5 & $21.6 \%$ & 9.7 & $0.9 \%$ \\
\hline University & 2.9 & $10.3 \%$ & 9.3 & $1.3 \%$ & 3.0 & $14.8 \%$ & 9.7 & $0.5 \%$ \\
\hline $\begin{array}{l}\text { Unemployment } \\
\text { rate }=10 \%\end{array}$ & 5.2 & $43.3 \%$ & 7.8 & $13.1 \%$ & 5.3 & $43.9 \%$ & 8.9 & $5.9 \%$ \\
\hline $\begin{array}{l}\text { Single with two } \\
\text { children }\end{array}$ & 4.8 & $36.8 \%$ & 7.2 & $13.7 \%$ & 5.4 & $45.0 \%$ & 7.7 & $12.6 \%$ \\
\hline $\begin{array}{l}\text { Married with } \\
\text { two children }\end{array}$ & 6.6 & $66.5 \%$ & 5.9 & $33.1 \%$ & 6.6 & $66.5 \%$ & 5.7 & $33.4 \%$ \\
\hline \multicolumn{9}{|l|}{ Panel B: } \\
\hline Age $=45$ & 2.4 & $5.3 \%$ & 9.6 & $0.3 \%$ & 3.4 & $21.1 \%$ & 9.8 & $0.5 \%$ \\
\hline High School & 2.3 & $4.5 \%$ & 9.7 & $0.3 \%$ & 2.5 & $10.5 \%$ & 10.0 & $0.1 \%$ \\
\hline University & 1.9 & $2.0 \%$ & 9.8 & $0.0 \%$ & 2.1 & $6.2 \%$ & 10.0 & $0.0 \%$ \\
\hline $\begin{array}{l}\text { Unemployment } \\
\text { rate }=10 \%\end{array}$ & 3.3 & $15.4 \%$ & 9.2 & $2.3 \%$ & 3.6 & $22.9 \%$ & 9.8 & $0.7 \%$ \\
\hline $\begin{array}{l}\text { Single with two } \\
\text { children }\end{array}$ & 3.1 & $10.6 \%$ & 8.8 & $2.0 \%$ & 3.5 & $20.0 \%$ & 9.3 & $2.2 \%$ \\
\hline $\begin{array}{l}\text { Married with } \\
\text { two children }\end{array}$ & 4.5 & $31.7 \%$ & 8.1 & $8.4 \%$ & 4.6 & $33.0 \%$ & 8.1 & $7.6 \%$ \\
\hline
\end{tabular}

\footnotetext{
${ }^{8}$ Base category is a man/woman who has a compulsory education, lives in an urban area with 5 percent unemployment rate, is single, has no children, and arrived to Sweden 15 years ago, between 1976 and 1980.
} 